\title{
FLOODS IN THE ENGLISH RIVER BASIN, IOWA
}

\section{U.S. GEOLOGICAL SURVEY}

WATER-RESOURCES INVESTIGATIONS

OPEN-FILE REPORT 81-67

Prepared in cooperation with

Highway Research Board

Highway Division

Iowa Department of Transportation
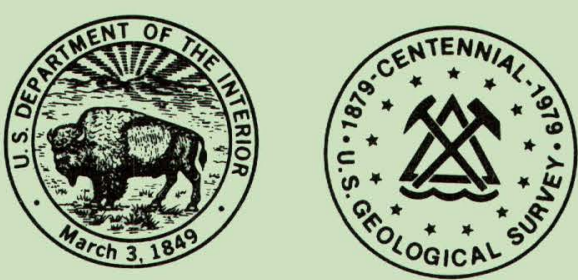
UNITED STATES

DEPARTMENT OF THE INTERIOR

GEOLOGICAL SURVEY
U.S. GEOLOGICAL SURVEY

P.O. BOX 1230

IOWA CITY, IA 52244

C. 3

LIBRARY COPY

FLOODS IN THE ENGLISH RIVER BASIN, IOWA

By A.J. Heinitz and D.E. Riddle

U.S. GEOLOGICAL SURVEY

WATER-RESOURCES INVESTIGATIONS

OPEN-FILE REPORT 81-67

Prepared in cooperation with the

Highway Research Board

Highway Division

Iowa Department of Transportation 

05-4551.40 North English River near Montezuma, Iowa

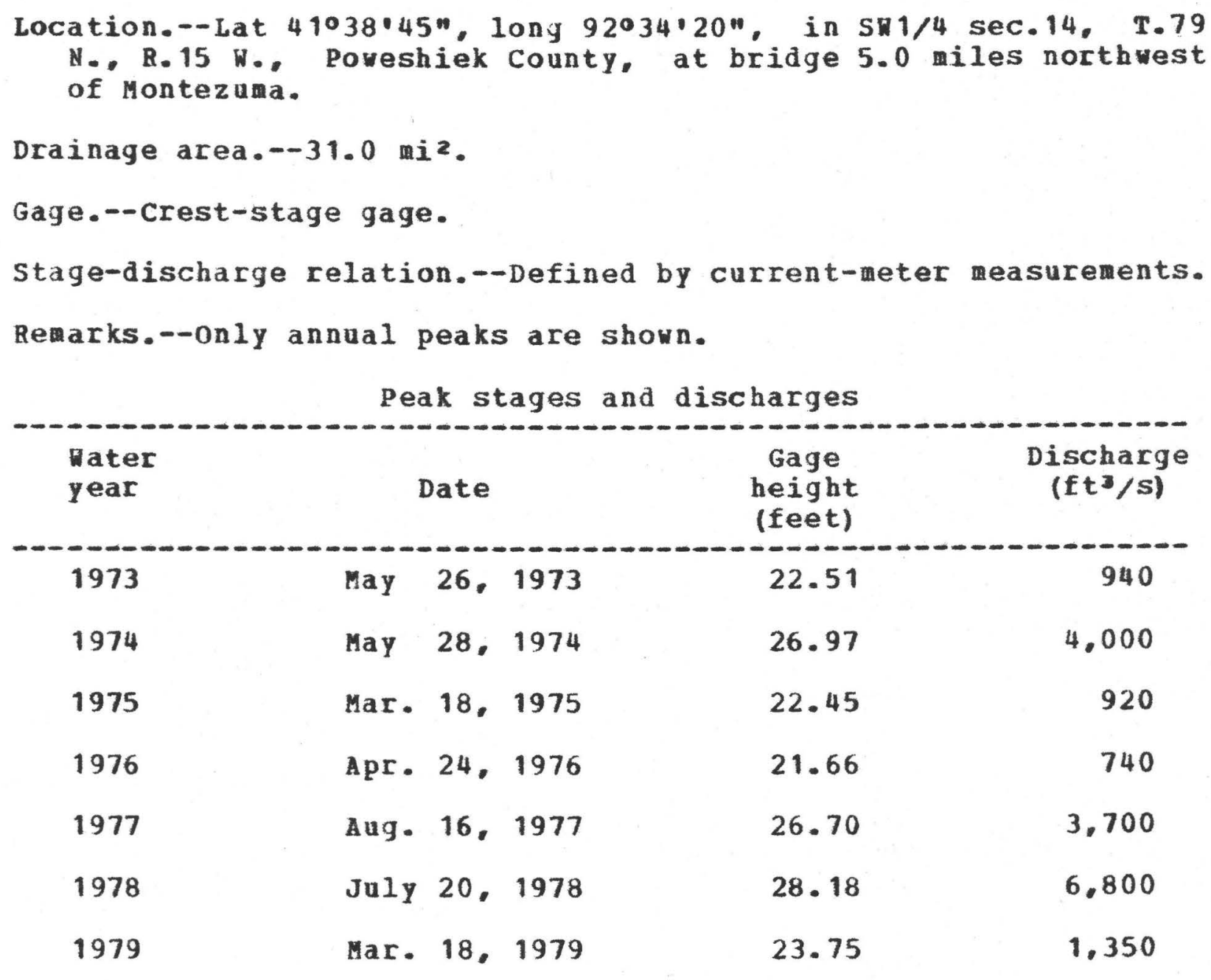




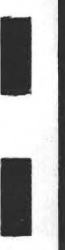

I

I

I

I

I

I

I

I)

I

I

I

I

I

I

I

I 
05-4551.50 North English River near Montezuma, Iowa (Prior to 1970 published as "North Fork English River")

(Discontinued 1973)

Location.--Iat $41039^{\circ}, 1$ long $92^{\circ} 33^{\circ}$, in Sw1/4 sec. 13, T.79 N.. R. 15 H.. Poweshiek County, at bridge on U.S. Highway 6.3, 5 miles northwest of Montezuma.

Drainage area.- -34.0 mi

Gage.--Crest-stage gage.

Stage-discharge relation.--Defined by current-meter and indirect ieasurements.

Rewarks.--only annual peaks are shown.

peak stages and discharges

\begin{tabular}{|c|c|c|c|c|}
\hline $\begin{array}{l}\text { Water } \\
\text { year }\end{array}$ & & Date & $\begin{array}{c}\text { Gage } \\
\text { height } \\
\text { (feet) }\end{array}$ & $\begin{array}{c}\text { Discharge } \\
\text { (ft } 3 / \mathrm{s})\end{array}$ \\
\hline 1953 & Mar. & 24.1953 & 13.25 & 4.240 \\
\hline 1954 & Aug. & 26,1954 & 7.47 & 1.270 \\
\hline 1955 & & -- & a & $<450$ \\
\hline 1956 & June & 20,1956 & 7.08 & 1.120 \\
\hline 1957 & July & 28.1957 & 12.22 & 3,700 \\
\hline 1958 & MaY & 31.1958 & 9.13 & 1.940 \\
\hline 1959 & Mar. & 20.1959 & 13.18 & 4.190 \\
\hline 1960 & Mar. & 30,1960 & 11.60 & 2.000 \\
\hline 1961 & Mar. & 13,1961 & 12.95 & 3.400 \\
\hline 1962 & & -- & $\mathbf{a}$ & b \\
\hline 1963 & Apr. & 28,1963 & 8.03 & 990 \\
\hline 1964 & & -- & a & b \\
\hline
\end{tabular}

a Peak stage did not reach bottom of gage.

b Discharge not determined. 
05-4551.50 North English River near Montezuma, Iowa-- (Continued) Peak stages and discharges

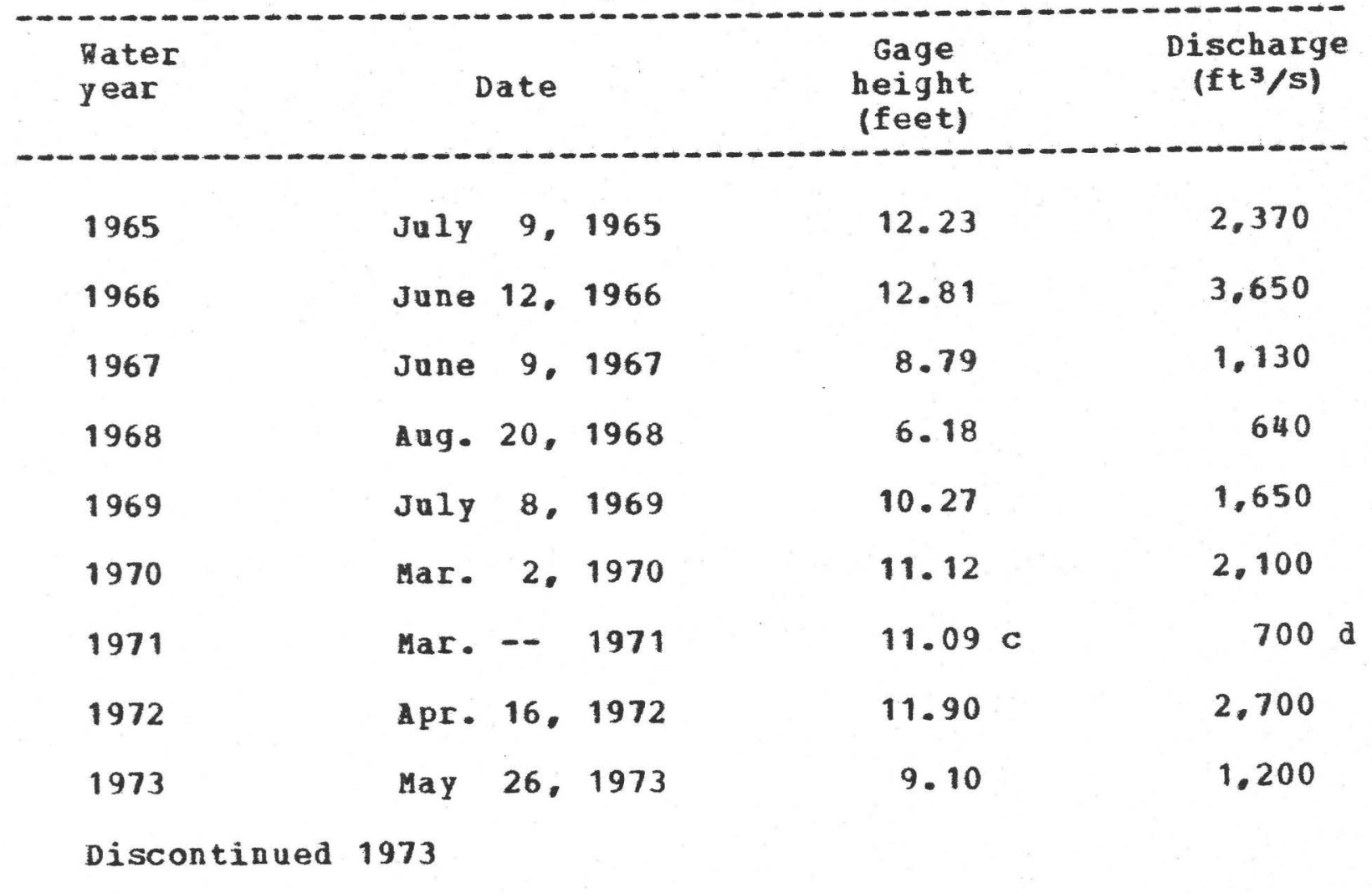

c Affected by ice.

d About. 


\section{5-4552.00 North English River near Guernsey, Iowa (Prior to 1970 published as "North Fork English River")}

Location.--Lat $41038^{\circ}$, long 92024\% near Sw corner sec.17, T.79 N. R.13 H.. Poweshiek County, at bridge, 2.2 miles west of Guernsey.

Drainage area.- $-68.7 \mathrm{mi}^{2}$

Gage.--Crest-stage gage.

Stage-discharge relation.--Defined by current-meter measurements. Remarks.--only annual peaks are shown.

Peak stages and discharges

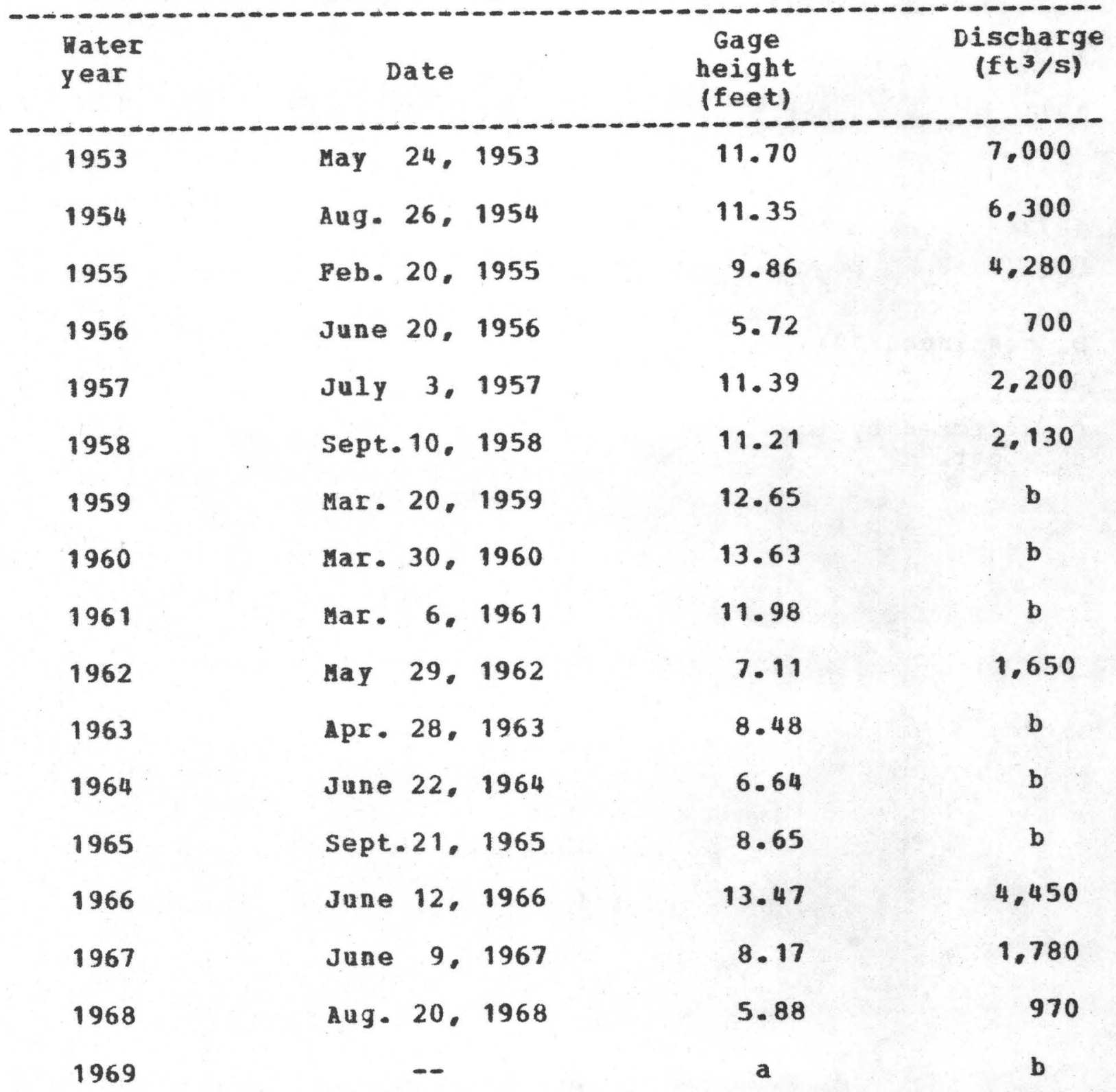

a peak stage did not reach botton of gage.

b Discharge not determined. 
05-4552.00 North English River near Guernsey, Iowa--(Continued) Peak stages and discharges

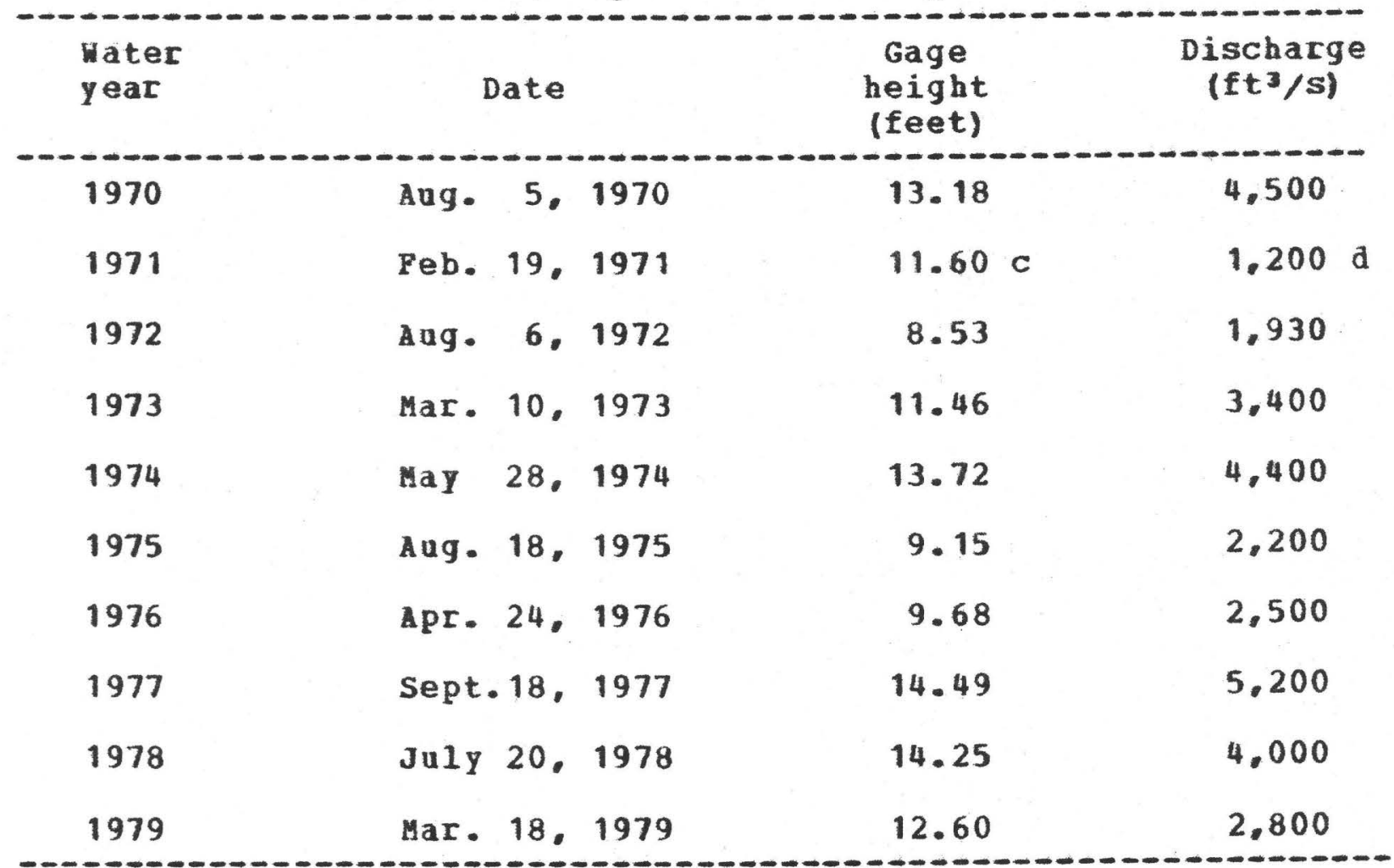

c Affected by ice.

d bout. 
05-4552.10 North English River at Guernsey, Iowa (Prior to 1970 published as "North Fork English River")

Location.--Lat $41038^{\circ}$, long $92021^{\prime}$, in $N 1 / 4$ sec. 22 , T.79 .. R. 13 W.. Poweshiek County, at bridge on State Highway 21, 1 mile southwest of Guernsey.

Drainage area.- $-81.5 \mathrm{mi}$.

Gage.--Crest-stage gage.

Stage-discharge relation.--Defined by current-meter and indirect measurements.

Rewarks.--only annual peaks are shown.

Peak stages and discharges

\begin{tabular}{|c|c|c|c|c|}
\hline $\begin{array}{l}\text { Water } \\
\text { year }\end{array}$ & & Date & $\begin{array}{c}\text { Gage } \\
\text { height } \\
\text { (feet) }\end{array}$ & $\begin{array}{c}\text { Discharge } \\
\left(\mathrm{ft}^{3} / \mathrm{s}\right)\end{array}$ \\
\hline 1960 & Jan. & 12. 1960 & 85.25 & 3,970 \\
\hline 1966 & June & 12. 1966 & 85.73 & 5.300 \\
\hline 1967 & Apr. & 13,1967 & 85.21 & 4.400 \\
\hline 1968 & & -- & $\mathbf{a}$ & $<1,860$ \\
\hline 1969 & July & 8. 1969 & 84.35 & 3.500 \\
\hline 1970 & Mar. & 2,1970 & 86.15 & 6.600 \\
\hline 1971 & Feb. & 19. 1971 & $83.86 \mathrm{c}$ & $1.400 \mathrm{~d}$ \\
\hline 1972 & Aug. & 6. 1972 & 85.25 & 4.400 \\
\hline 1973 & Mar. & 1. 1973 & 85.05 & 4,200 \\
\hline 1974 & May & 28.1974 & 85.66 & 5,000 \\
\hline 1975 & Mar. & 18. 1975 & 83.39 & 2.800 \\
\hline 1976 & Apr. & $24 \cdot 1976$ & 85.03 & 4.200 \\
\hline 1977 & Sept. & 18. 1977 & 87.36 & 7,000 \\
\hline 1978 & July & 20.1978 & 86.62 & 5.500 \\
\hline 1979 & Mar. & 18,1979 & 85.44 & 3.600 \\
\hline
\end{tabular}

a Peak stage did not reach botton of gage.

c Affected by ice.

d about. 


\section{5-4552.30 Deep River at Deep River. Iowa}

Location.--Lat $41035^{\prime}$, long $92021^{\prime}$, in $\mathrm{S} 11 / 4 \mathrm{sec} .3 . \mathrm{T} .78 \mathrm{~N}$. R. 13 H.. Poweshiek County. at bridge on state Highway 21, 1 mile northeast of Deep River.

Drainage area.--30.5 mi2.

Gage.--Crest-stage gage.

stage-discharge relation.--Defined by current-meter and indirect measurements.

Remarks.--only annual peaks are shown.

Peak stages and discharges

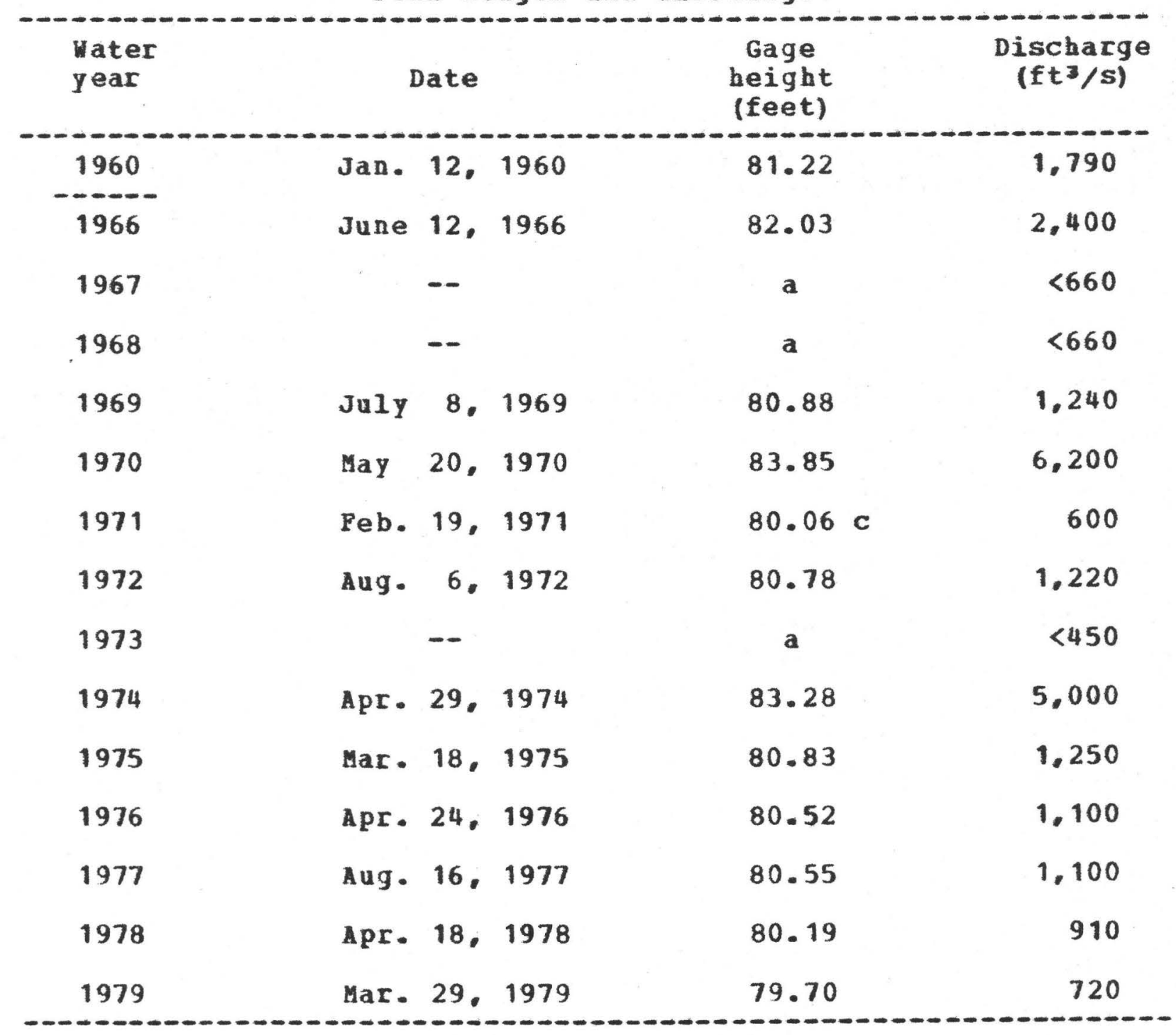

a Peak stage did not reach bottom of gage.

c Afected by ice. 
05-4552.80 South English River tributary near Barnes City. Iowa (Prior to 1967 published as "South Fork English River tributary")

Location.--Lat $41033^{\circ}$, long 92038\%, near NE corner sec.21, T.78 N. R.14. W.. Poweshiek County, at bridge, 3 miles north of Barnes City.

Drainage area.-- $2.41 \mathrm{mi}^{2}$.

Gage.--Crest-stage gage.

stage-discharge relation.--Defined by current-meter and indirect measurements.

Remarks.--only annual peaks are shown.

peak stages and discharges

\begin{tabular}{|c|c|c|c|c|}
\hline $\begin{array}{l}\text { Water } \\
\text { year }\end{array}$ & & Date & $\begin{array}{c}\text { Gage } \\
\text { height } \\
\text { (feet) }\end{array}$ & $\begin{array}{c}\text { Discharge } \\
\left(\mathrm{ft}^{3} / \mathrm{s}\right)\end{array}$ \\
\hline 1953 & June & 28,1953 & 7. 38 & 400 \\
\hline 1954 & Aug. & 26,1954 & 8.21 & 650 \\
\hline 1955 & oct. & 10.1954 & 6.19 & 170 \\
\hline 1956 & Aug. & 12,1956 & 6.77 & 263 \\
\hline 1957 & July & 3. 1957 & 7.38 & 400 \\
\hline 1958 & Aug. & $15 \cdot 1958$ & 6.72 & 255 \\
\hline 1959 & $\mathrm{July}$ & 18,1959 & 8.55 & 793 \\
\hline 1960 & June & 19.1960 & 8.57 & 690 \\
\hline 1961 & Ju1Y & $27 \cdot 1961$ & 8.81 & 784 \\
\hline 1962 & Nov. & 16.1961 & 4.85 & 123 \\
\hline 1963 & Mar. & 4. 1963 & 5.21 & 145 \\
\hline 1964 & June & 22.1964 & 5.34 & 1152 \\
\hline 1965 & July & 9. 1965 & 8.56 & 686 \\
\hline 1966 & June & 12. 1966 & 8.33 & 606 \\
\hline 1967 & Apr. & 13. 1967 & 7.93 & 480 \\
\hline 1968 & Aug. & 20,1968 & 7.58 & 385 \\
\hline 1969 & & -- & 6.13 & b \\
\hline
\end{tabular}


05-4552.80 South English River tributary near Barnes City, Iowa-(continued)

Peak stages and discharges

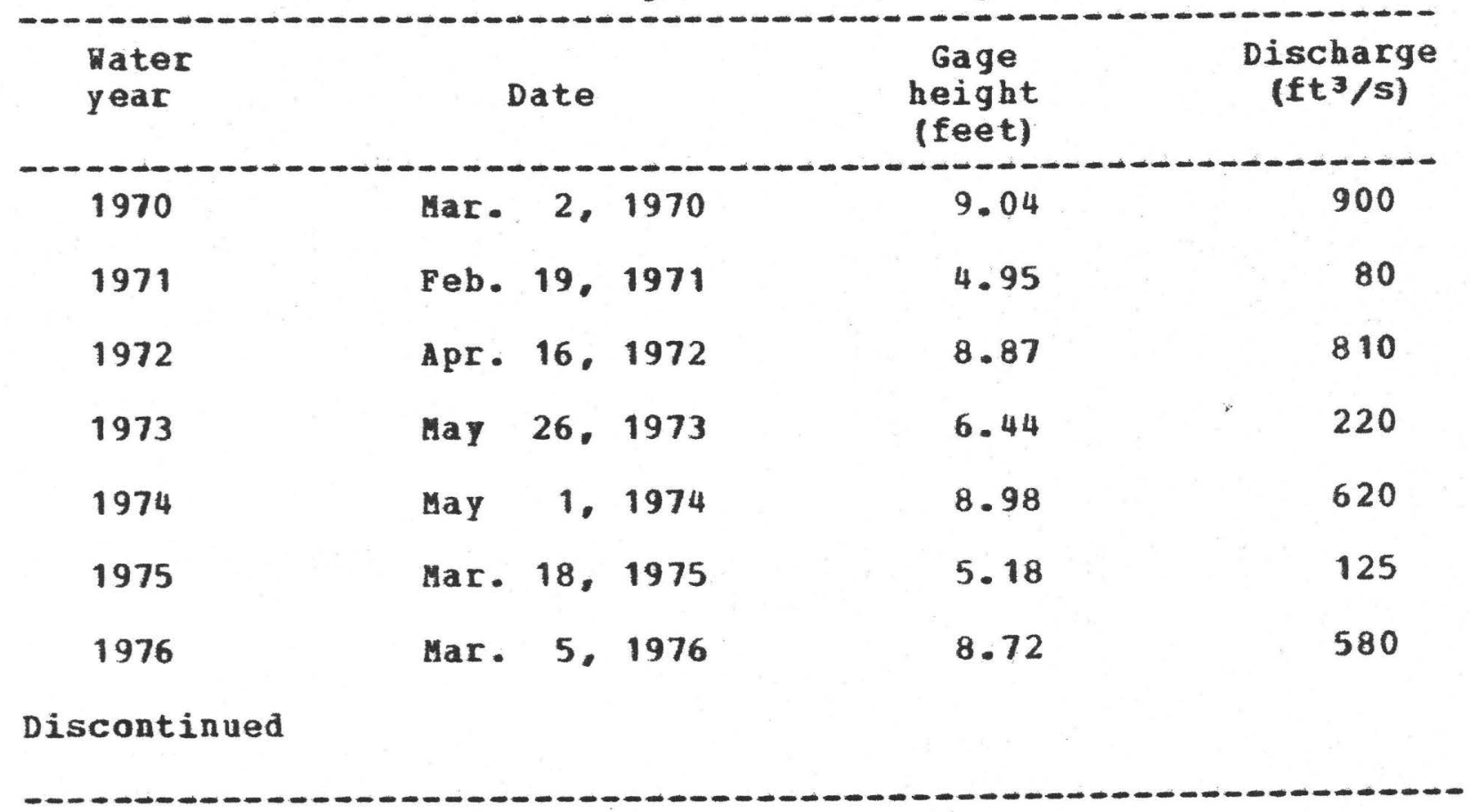


05-4553.00 South English River near Barnes City. Iowa (Prior to 1967 published as "South Fork English River")

Location.--Lat $41031^{\prime}$, Iong 92028\%, near w corner sec.34, T.78 N.. R.14... Poweshiek County. at bridge, 1 mile north of Barnes city.

Drainage area.--11.5 $\mathrm{mi}^{2}$.

Gage.--Crest-stage gage.

stage-discharge relation.--Defined by current-meter and indirect measurements.

Rewarks.--only annual peaks are shown.

peak stages and discharges

\begin{tabular}{|c|c|c|c|c|}
\hline $\begin{array}{l}\text { Water } \\
\text { year }\end{array}$ & & ate & $\begin{array}{c}\text { Gage } \\
\text { height } \\
\text { (feet) }\end{array}$ & $\begin{array}{c}\text { Discharge } \\
\left(\mathrm{ft}^{3} / \mathrm{s}\right)\end{array}$ \\
\hline 1953 & June & 28.1953 & 11.40 & 478 \\
\hline 1954 & Aug. & 26.1954 & 10.88 & 352 \\
\hline 1955 & Apr. & 24.1955 & 9.20 & 157 \\
\hline 1956 & Aug. & $12 \cdot 1956$ & 8.43 & 121 \\
\hline 1957 & July & 3.1957 & 9.50 & 172 \\
\hline 1958 & July & 31.1958 & 10.87 & 318 \\
\hline 1959 & JuLY & 18.1959 & 11.73 & 611 \\
\hline 1960 & July & 12.1960 & 12.14 & 865 \\
\hline 1961 & July & 27.1961 & 13.43 & 1.790 \\
\hline 1962 & Mar. & 19.1962 & 11.49 & 666 \\
\hline 1963 & Mar. & 4. 1963 & 10.80 & 298 \\
\hline 1964 & June & $22 \cdot 1964$ & 11.42 & 1484 \\
\hline 1965 & July & 9. 1965 & 12.07 & 812 \\
\hline 1966 & June & 12.1966 & $12 \cdot 25$ & 1.130 \\
\hline 1967 & Apr. & 13.1967 & 11.62 & 650 \\
\hline 1968 & Aug. & 20.1968 & 9.87 & 300 \\
\hline 1969 & $\mathrm{Ju} 1 \mathrm{Y}$ & 8. 1969 & 12.95 & 1.600 \\
\hline 1970 & Aug. & 5,1970 & 13.16 & 1,850 \\
\hline
\end{tabular}


05-4553.00 South English River near Barnes City. Iowa--(Continued) Peak stages and discharges

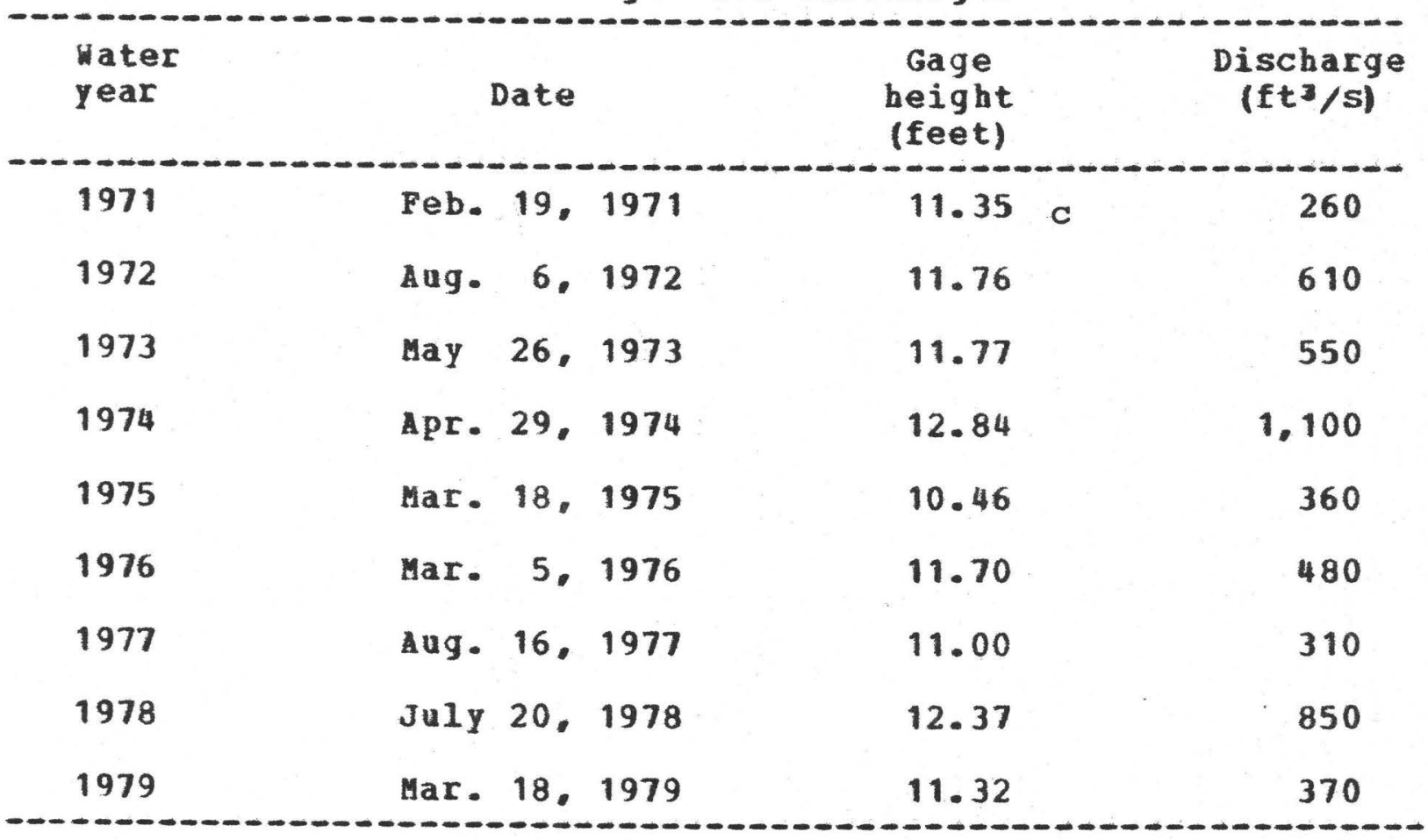

c Affected by ice 


\section{UNITED STATES DEPARTMENT OF THE INTERIOR \\ CECIL D. ANDRUS, Secretary}

GEOLOGICAL SURVEY

H. William Menard, Director 
05-4553.50 South English River tributary No. 2 near Montezuma, Iowa (Prior to 1967 published as "South Fork Bnglish River tributary No. $2^{\text {") }}$ )

Location.--Lat $41034^{\circ}$. Iong $922^{\circ} 7^{\circ}$, near sw corner sec.11, t.78 N.. B. 14 W.. Poweshiek County, at box culvert, 4 miles southeast of Montezuna.

Drainage area.- $0.62 \quad i^{2}$.

Gage.--crest-stage gage.

stage-discharge relation.--Defined by current-meter and indirect measurements.

Remarks.--only annual peaks are shown.

peak stages and discharges

\begin{tabular}{|c|c|c|c|c|c|}
\hline $\begin{array}{l}\text { Mater } \\
\text { year }\end{array}$ & & bate & & $\begin{array}{c}\text { Gage } \\
\text { height } \\
\text { (feet) }\end{array}$ & $\begin{array}{c}\text { Discharge } \\
\left(\mathrm{ft}^{3} / \mathrm{s}\right)\end{array}$ \\
\hline 1953 & June & 28. & 1953 & 8.53 & 31 \\
\hline 1954 & Aug. & 26 & 1954 & 8.44 & 28 \\
\hline 1955 & Apr. & 24. & 1955 & 8.27 & 23 \\
\hline 1956 & Aug. & 12. & 1956 & 8.52 & 31 \\
\hline 1957 & July & 3. & 1957 & 8.29 & 24 \\
\hline 1958 & Sept. & 10 & 1958 & 8.39 & 27 \\
\hline 1959 & May & 19. & 1959 & 9.43 & 58 \\
\hline 1960 & June & 19 & 1960 & 11.18 & 134 \\
\hline 1961 & July & 27. & 1961 & 13.65 & 344 \\
\hline 1962 & Mar. & 19. & 1962 & 8.68 & 35 \\
\hline 1963 & & - & & $\mathbf{a}$ & $\left.\right|^{<19}$ \\
\hline 1964 & & $-\infty$ & & a & $<19$ \\
\hline 1965 & Ju1y & 9. & 1965 & 9.99 & 80 \\
\hline 1966 & June & 12 & 1966 & 9.87 & 75 \\
\hline 1967 & & -- & & a & $<19$ \\
\hline 1968 & & -- & & $\mathbf{a}$ & $<19$ \\
\hline
\end{tabular}

a Peak stage did not reach botton of gage. 
05-4553.50 South English River tributary No. 2 nr Montezuma. Iowa-(Continued)

Peak stages and discharges

\begin{tabular}{|c|c|c|c|c|c|}
\hline $\begin{array}{l}\text { Water } \\
\text { year }\end{array}$ & & ate & & $\begin{array}{c}\text { Gage } \\
\text { height } \\
\text { (feet) }\end{array}$ & $\begin{array}{c}\text { Discharge } \\
\left(\mathrm{ft}^{3} / \mathrm{s}\right)\end{array}$ \\
\hline 1969 & & -- & & a & $<19$ \\
\hline 1970 & May & 20 & 1970 & 9.98 & 77 \\
\hline 1971 & Peb. & 19. & 1971 & $8.37 \mathrm{c}$ & 20 \\
\hline 1972 & May & 8. & 1972 & 10.74 & 210 \\
\hline 1973 & & -- & & $\mathbf{a}$ & $<19$ \\
\hline 1974 & May & 28 & 1974 & 13.53 & 340 \\
\hline 1975 & June & 18. & 1975 & 8.23 & 22 \\
\hline 1976 & Apr. & 24 & 1976 & 9.19 & 50 \\
\hline 1977 & Aug. & 16. & 1977 & 8.65 & 33 \\
\hline 1978 & July & 20 & 1978 & 9.40 & 60 \\
\hline 1979 & June & 27 & 1979 & 10.59 & 100 \\
\hline
\end{tabular}

a Peak stage did not reach bottom of gage.

c affected by ice. 
Location.--Lat $41027 \cdot 59^{\prime \prime}$, long $910420^{\circ}$, in SE1/4 SE1/4 sec.13. T.77 .. R. 8 W.. Mashington County. on right bank $30 \mathrm{ft}$ upstrea frow bridge on state kighway 1, 0.8 mile south of Kalona, 1.1 mile upstream from Camp Creek, 4.5 miles downstream from Swith creek, and 14.5 miles upstrea from outh.

Drainage area.- $-573 \mathrm{mi}^{2}$.

Gage.--Water-stage recorder. Datum of gage is $633.45 \mathrm{ft}$ Vational Geodetic Vertical Datun of 1929 (levels by Corps of Engineers). Prior to Dec. 27, 1939, nonrecording gage $30 \mathrm{ft}$ dounstrea at same datum.

stage-discharge relation.--Defined by current-meter measurements. Flood stage. $--14 \mathrm{ft}$.

Remarks.-Base for partial-duration series, $4.000 \mathrm{ft}^{3} / \mathrm{s}$. Base was 2,800 prior to 1966.

Peak stages and discharges

\begin{tabular}{|c|c|c|c|c|}
\hline $\begin{array}{l}\text { Water } \\
\text { year }\end{array}$ & & Date & $\begin{array}{l}\text { Gage } \\
\text { height } \\
\text { (feet) }\end{array}$ & $\begin{array}{c}\text { Discharge } \\
\left(\mathrm{ft}^{3} / \mathrm{s}\right)\end{array}$ \\
\hline 1930 & June & 30,1930 & $19.90 \mathrm{a}$ & 18.500 \\
\hline 1940 & Har. & 19.1940 & 7.35 & 1.400 \\
\hline 1941 & Jaly & 2. 1941 & 10.0 & 2.490 \\
\hline 1942 & Hov. & 2. 1941 & 11.8 & 3.340 \\
\hline 1943 & $\begin{array}{l}\text { Peb. } \\
\text { lay } \\
\text { May } \\
\text { Aug. }\end{array}$ & $\begin{array}{r}5.1943 \\
1 \% 1943 \\
17.1943 \\
5.1943\end{array}$ & $\begin{array}{l}13.8 b \\
11.1 \\
12.8 \\
18.11\end{array}$ & $\begin{array}{r}3,960 c \\
3,000 \\
4,030 \\
10,700\end{array}$ \\
\hline 1944 & $\begin{array}{l}\text { Apr. } \\
\text { Apr. } \\
\text { May } \\
\text { Way } \\
\text { June. }\end{array}$ & $\begin{array}{l}16,1944 \\
23,1944 \\
22,1944 \\
27.1944 \\
17,1944\end{array}$ & $\begin{array}{l}11.9 \\
15.3 \\
15.9 \\
13.8 \\
13.2\end{array}$ & $\begin{array}{l}3.660 \\
6.070 \\
6.810 \\
4.730 \\
4.290\end{array}$ \\
\hline 1945 & $\begin{array}{l}\text { Apr. } \\
\text { שay } \\
\text { tay } \\
\text { June } \\
\text { June }\end{array}$ & $\begin{array}{r}17.1945 \\
16.1945 \\
18: 1945 \\
1: 1945 \\
12: 1945\end{array}$ & $\begin{array}{l}11.7 \\
12.8 \\
11.9 \\
11.5 \\
12.7\end{array}$ & $\begin{array}{l}3.720 \\
4.300 \\
3.790 \\
3.530 \\
4.280\end{array}$ \\
\hline
\end{tabular}

a Fron floodmark, from information by local resident.

b iffected by ice.

c about. 
05-4555.00 English River at Kalona, Iowa--(Continued)

Peak stages and discharges

\begin{tabular}{|c|c|c|c|c|c|}
\hline $\begin{array}{l}\text { Water } \\
\text { Year }\end{array}$ & & Date & & $\begin{array}{l}\text { Gage } \\
\text { height } \\
\text { (feet) }\end{array}$ & $\begin{array}{c}\text { Discharge } \\
\left(\mathrm{ft}^{3} / \mathrm{s}\right)\end{array}$ \\
\hline 1946 & $\begin{array}{l}\text { Jan. } \\
\text { Mar. } \\
\text { May } \\
\text { June }\end{array}$ & $\begin{array}{r}7 \\
18 \\
5 \\
20\end{array}$ & $\begin{array}{l}1946 \\
1946 \\
1946 \\
1946\end{array}$ & $\begin{array}{l}19.74 \\
11.3 \\
13.2 \\
15.3\end{array}$ & $\begin{array}{r}16.400 \\
3.530 \\
4.860 \\
6.400\end{array}$ \\
\hline 1947 & $\begin{array}{l}\text { Mar. } \\
\text { Apr. } \\
\text { Apr. } \\
\text { Apr. } \\
\text { May } \\
\text { June } \\
\text { June } \\
\text { June } \\
\text { June } \\
\text { July }\end{array}$ & $\begin{array}{r}13 . \\
6 \% \\
11 \% \\
21 \\
30 \\
3 \% \\
7 \\
15 \\
23 \\
2 \%\end{array}$ & $\begin{array}{l}1947 \\
1947 \\
1947 \\
1947 \\
1947 \\
1947 \\
1947 \\
1947 \\
1947 \\
1947\end{array}$ & $\begin{array}{l}10.4 \\
16.6 \\
12.3 \\
14.6 \\
10.8 \\
13.3 \\
14.6 \\
13.4 \\
11.7 \\
14.1\end{array}$ & $\begin{array}{l}2.860 \\
7.900 \\
3.950 \\
5.620 \\
3.230 \\
4.830 \\
5.880 \\
4.940 \\
3.790 \\
5.470\end{array}$ \\
\hline 1948 & $\begin{array}{l}\text { Peb. } \\
\text { Mar. } \\
\text { Mar. } \\
\text { July }\end{array}$ & $\begin{array}{l}29 \\
17 \\
20 \\
22\end{array}$ & $\begin{array}{l}1948 \\
1948 \\
1948 \\
1948\end{array}$ & $\begin{array}{l}15.7 \\
15.6 \\
13.9 \\
12.8\end{array}$ & $\begin{array}{l}6.680 \\
6.630 \\
5.040 \\
4.290\end{array}$ \\
\hline 1949 & $\begin{array}{l}\text { Jan. } \\
\text { Feb. } \\
\text { Mar. }\end{array}$ & $\begin{array}{r}17 \\
26 \\
6\end{array}$ & $\begin{array}{l}1949 \\
1949 \\
1949\end{array}$ & $\begin{array}{l}10.2 \\
15.7 \mathrm{~b} \\
14.3\end{array}$ & $\begin{array}{l}2,870 \\
4,000 \mathrm{c} \\
5,770\end{array}$ \\
\hline 1950 & $\begin{array}{l}\text { Mar. } \\
\text { Jane } \\
\text { June }\end{array}$ & $\begin{array}{l}7 . \\
19 . \\
25\end{array}$ & $\begin{array}{l}1950 \\
1950 \\
1950\end{array}$ & $\begin{array}{l}16.1 \\
17.33 \\
10.6\end{array}$ & $\begin{array}{l}8.550 \\
9.450 \\
3.110\end{array}$ \\
\hline 1951 & $\begin{array}{l}\text { Feb. } \\
\text { Mar. } \\
\text { Apr. } \\
\text { May } \\
\text { May } \\
\text { June } \\
\text { July } \\
\text { July } \\
\text { Aug. }\end{array}$ & 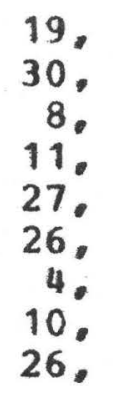 & $\begin{array}{l}1951 \\
1951 \\
1951 \\
1951 \\
1951 \\
1951 \\
1951 \\
1951 \\
1951\end{array}$ & $\begin{array}{l}12.26 \\
11.84 \\
11.61 \\
10.46 \\
12.70 \\
11.24 \\
10.82 \\
11.06 \\
14.74\end{array}$ & $\begin{array}{l}3.700 \mathrm{c} \\
3.860 \\
3.740 \\
3.080 \\
4.490 \\
3.500 \\
3.260 \\
3.440 \\
6.130\end{array}$ \\
\hline 1952 & $\begin{array}{l}\text { Nov. } \\
\text { Mar. } \\
\text { Mar. } \\
\text { May } \\
\text { June }\end{array}$ & $\begin{array}{l}13 \\
12 \\
19 \\
24 \\
21\end{array}$ & $\begin{array}{l}1951 \\
1952 \\
1952 \\
1952 \\
1952\end{array}$ & $\begin{array}{l}12.09 \\
15.47 \\
10.12 \\
11.02 \\
10.18\end{array}$ & $\begin{array}{l}3.930 \\
6.840 \\
2.870 \\
3.380 \\
2.920\end{array}$ \\
\hline 1953 & $\begin{array}{l}\text { Peb. } \\
\text { Mar. }\end{array}$ & $\begin{array}{l}21 . \\
31 \%\end{array}$ & $\begin{array}{l}1953 \\
1953\end{array}$ & $\begin{array}{l}14.43 \\
10.27\end{array}$ & $\begin{array}{l}5,860 \\
2.970\end{array}$ \\
\hline
\end{tabular}

b Affected by ice.

c about. 
05-4555.00 English River at Kalona. Iowa-- (Continued)

Peak stages and discharges

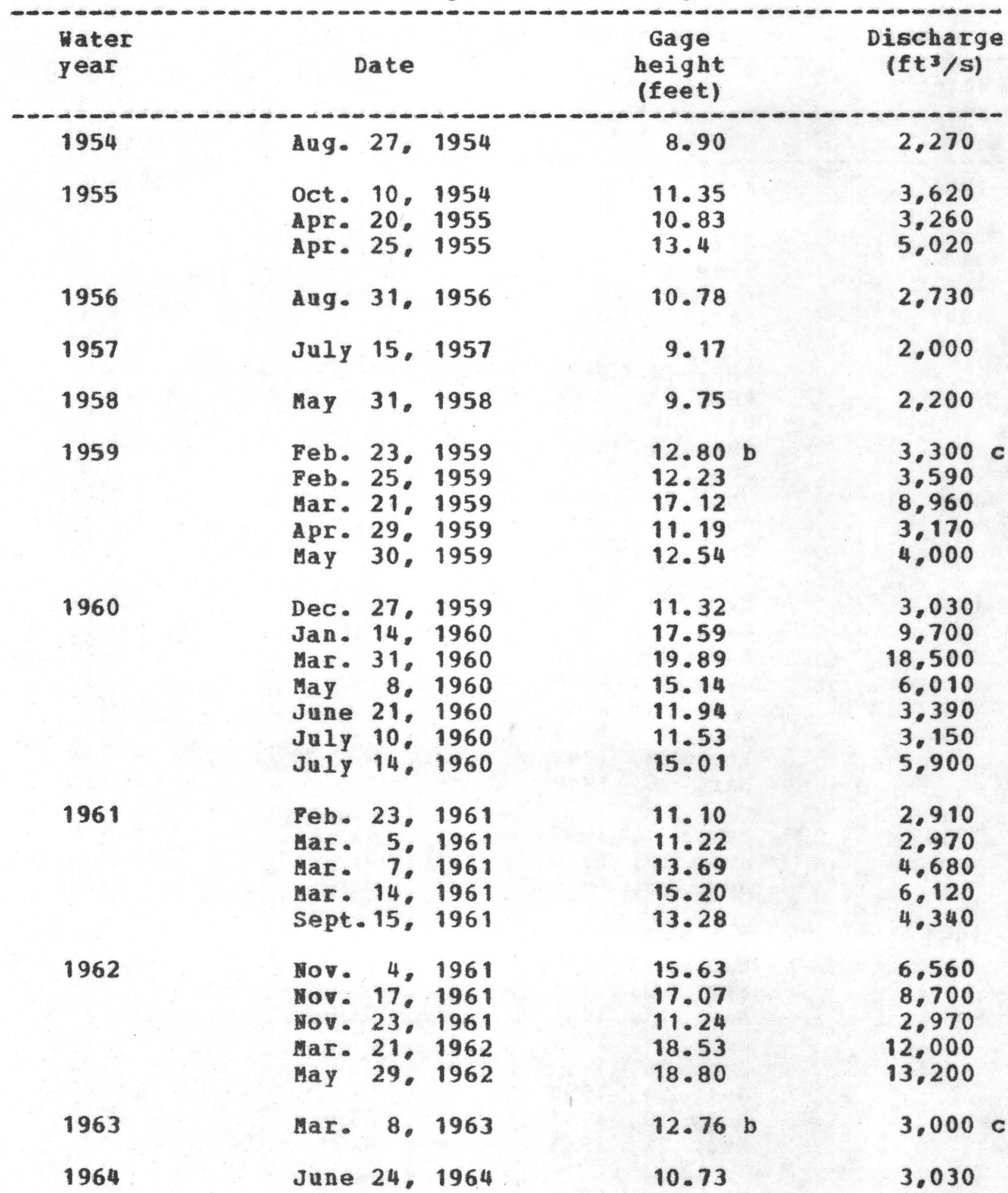

b Affected by ice.

c About. 
05-4555.00 English River at Kalona, Iova--(Continued)

Peak stages and discharges

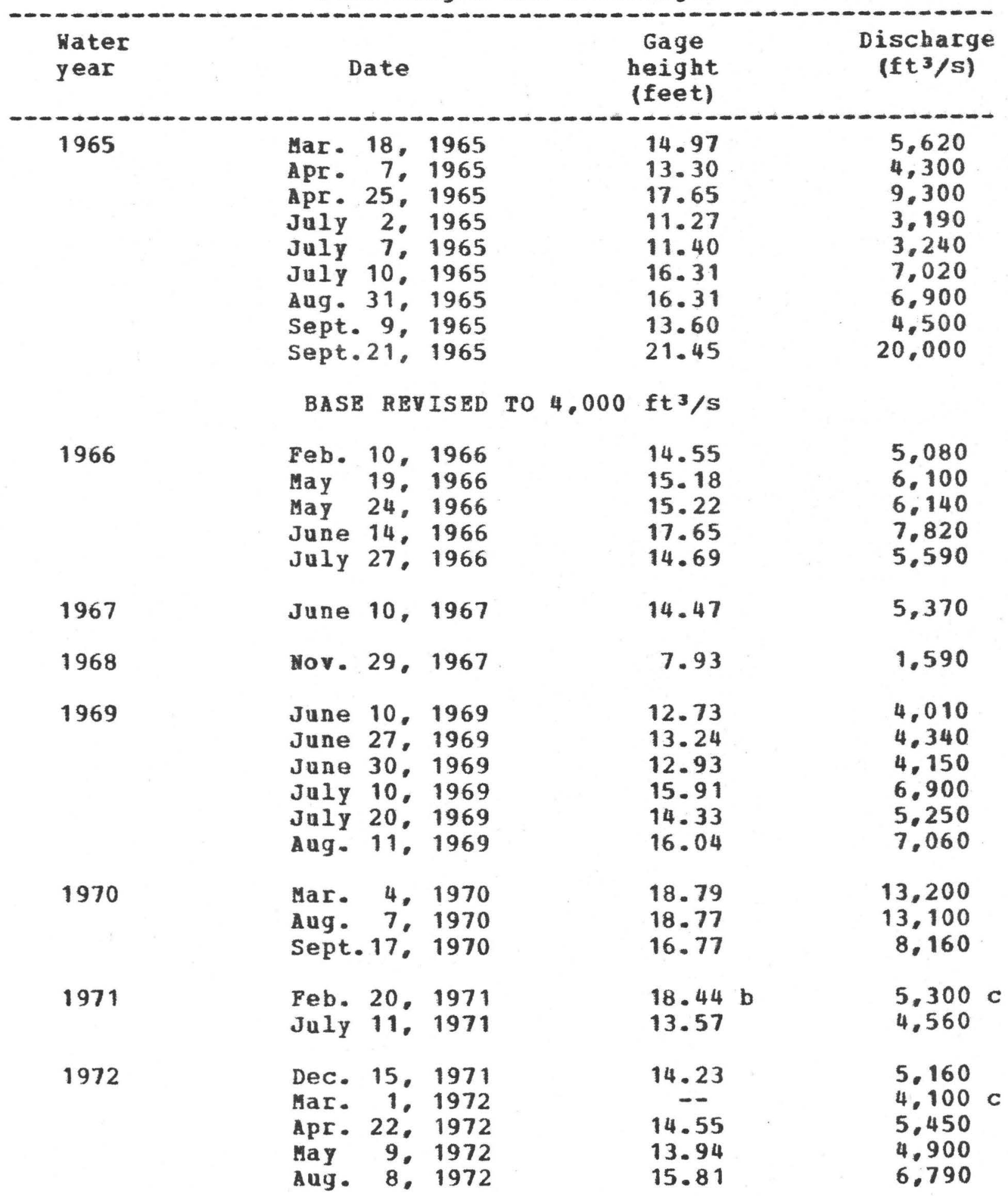

b Afected by ice.

c ibout. 
05-4555.00 English River at Kalona. Iowa-- (Continued)

Peak stages and discharges

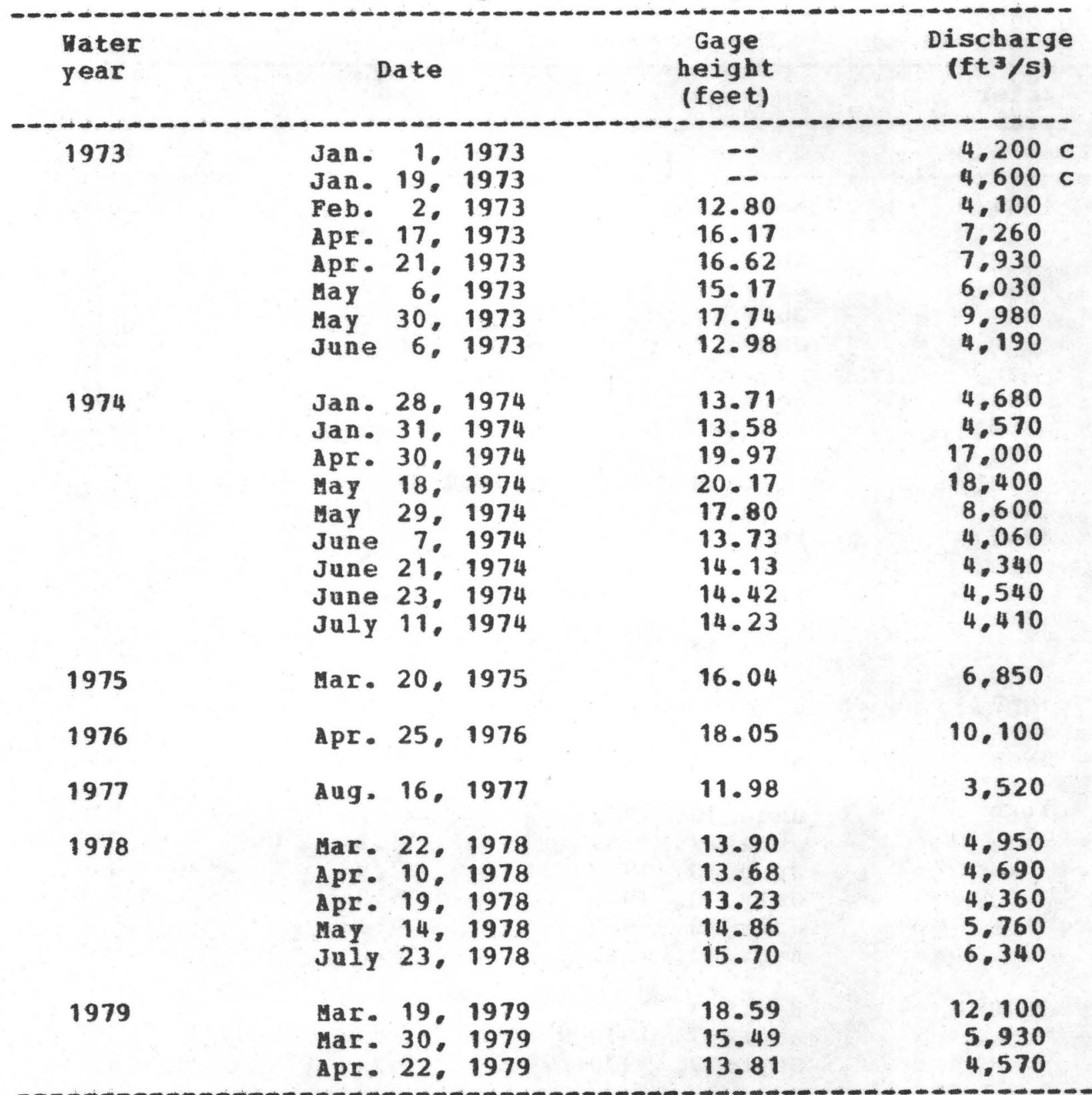

c about. 


\section{5-4555.50 Bulgers Run near Riverside, Iowa}

Location.--Lat $41029^{\circ}$. Iong $91038^{\circ}$, in SB1/4 sec.11, T.77 N.. R.7

H. Mashington County.

iles west of Riverside.

at bridge on state Highway $22,2.5$

Drainage area.--6.31 $\mathrm{mi}^{2}$.

Gage.--Crest-stage gage.

Stage-discharge relation.--Defined by current-meter measurements. Remarks.--only annual peaks are shown.

Peak stages and discharges

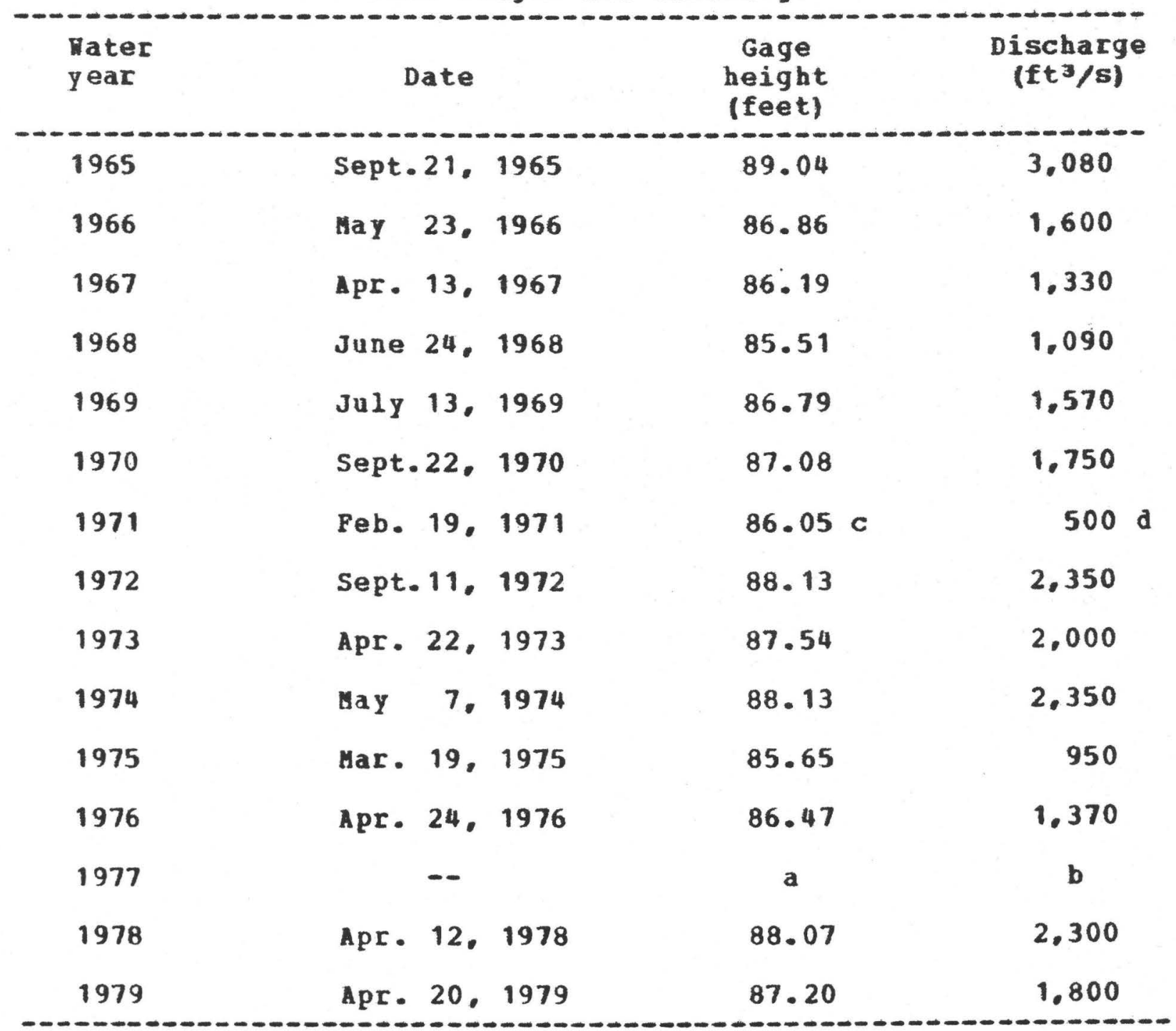

a Peak stage did not reach botton of gage.

b Discharge not deterined.

c affected by ice.

d about. 
ENGLISH RIVER BASIN

IOWA

The temporary bench arks listed in this tabulation have been established by the Vater Resources Division, Iowa District, U.S. Geological survey. Elevations for the bench marks were established by the U.S. Geological survey except those for which credit is given in the description of the bench ark. The leveling work was done as a part of a strea profile project cooperatively financed by the Highway Research Board, Highway Division. Iowa Department of Transportation and the 0.5. Geological Survey.

The streams covered by the level work were the English River. the North English River to near Guernsey, the South English River to Barnes City and the lower reaches of the Middle English and Deep Rivers.

Level lines to establish the third order accuracy bench marks shown herein vere run frow first or second order bench marks established and adjusted by the National Geodetic survey or from third order bench marks established and adjusted by the 0.S. Geological survey, Topographic division. Errors of closure in the Water Resources Division's level work were adjusted throughout the line to the elevations published by the National Geodetic Survey and the ropographic Division. These bench marks are repeated in this listing. All elevations are in National Geodetic Vertical Datum of 1929. 


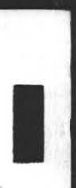

I

I

I

I

I

I

I

I

I

I

I

I

I

I

I

I

I

I

I 
The bench arks have been identified by an index number which is composed of the congressional township, range, and section number and the quarter-section in which they are located. The township and range numbers have been combined into a four-digit number, such as 8030 for township 80 north and range 30 west. This is followed by a dash and the section number in wich the wark is located. Within the section, the quarter in which the mark is located is designated by ME, SE, $N$, and SW. number in parentheses following this letter designation indicates the number of the mark in that particular quarter section. The index number serves to describe the landline location of the aark without further reference in the body of the description.

Standard marks such as chiseled squares and crosses vere used on concrete or steel. On trees or poles a 20-penny pole spike driven horizontally through a short piece of 1/8-inch galvanized pipe, or a railroad spike was used. Existing marks were used wherever available and the agency responsible for the mark, when known, is indicated in the description. Marks indicated as, (REF BREMCB POIMT). vere established to permit water surface elevations to be determined by use of a tape and weight. The terns "right and left" in the descriptions are deternined as vieved facing in the direction of the flow of the streas.

Aditional information, if arailable, can be obtained by uriting to the following adaress: U.S. Geological survey, P.O. Box 1230, 400 South clinton Street, Iowa City. Iowa 52244. 
7706-15 NW (1) - (FEFERENCE FOINT) About 2 miles east of Fiverside: at hishway 218 bridse over English Fiver, at center downstrean vertical truss menter, on sufport for tof suardrail, a filed arrow.

Elev. 634.34 feet.

7706-17 SW (1) - (REFERENCE FOINT) At Riverside, at county rosd W61 bridse aver Enslish River, on downstream curb et 30 th suerdrail fost from risht, a chiseled square.

Elev, 637.07 feet.

7706-18 SE (1) - At Fiverside, at county roas w61 bridse over Enslish River, on tor risht upstream winswall, a chiseled scuare, TEM-EX.

Elev. 635.70 feet.

7706-16 NE (1) - About 2 miles east of Riverside" at hishway 218 bridse over Enslish River, on risht upstream Fierg a standard US6s tablet staniped "q2-4".

7707-17 SW (1) - About 2 miles southeast of kzlona, at county road bridse over Engslish River, on left upstrean winswall, a chiseled souare* THBM-EY".

Elev, 648.65 feet.

7707-17 st (2) - (FEFERENCE FOINT) About 2 miles southeast of Kalonia, at count: roed bridse over Enslish River, on 2 nd downstream vertical bridse truse member from left, a filed arrow.

Elev. 660.36 feet.

7707-20 NW (1) - About 2 miles southeast of kalonas at a county road bridse over a shall creek, on risht downstream winswall, a chiseled sauare. Elev. $654+15$ peet.

7708-07 SE (1) - About $5+2$ miles west of Kalona" near a T-roed south 400 peet east and 23 feet north' a standard USGs tablet stamfed' 8 WEK $1969 \%$ ?

Elev, 707.392 feet.

7708-07 SW (1) - About 1.5 miles north of Wellman, at hishwas 114 bridse over English fiver, on left end of domntream curb, a chiseled cross.

Elev. 684,13 feet.

7708-07 5W (2) - (REFERENCE FOINT) About 1.5 miles north of Wellmans at hishwas 114 bridse over Enslish River, on top of downstream suardrail fosty 17 th post from risht end bridse, a chiseled arrow.

Elev: $686+93$ feet.

7708-08 5w (1) - About 4.5 miles west of Kalona, at a counts road bridse over Endish Fiver, at left downstrean $\mathrm{Fier}$ a chiseled cross on bolt, TBM12. Elev. 672.78 feet.

7708-08 SW (2) - (REFERENCE FOINT) About 4.5 miles west of Kalona, at counity road bridse over Enslish River, on ceriter downstrean vertical bridse member, a filed notch; $(92-5)$.

Elev, 680.40 feet.

$7708-10$ SE (1) - About 2 miles west of Kaloria, at hishwas 22 bridse over Enalish River, on tof of risht uFstream winsfost, a chiseled sauare.

Elev. 671.39 feet.

7708-10 SE (2) - (REFEREYCE POINT) About 2 miles west of Kalonag at hishway 22 bridse over Enslish Fiver, on top of downstrean suardrail fost, 11 th post from risht: a chiseled $u$.

Elev. 671.86 feet.

7708-13 SE (1) - About 1 mile south of Kalona, at hishway 1 bridse over Enslish Fiver, at azsehouse at risht upstrean end of bridse, on tof of triansular ster, at downstrean streamisrd corner.

Elev. 650.95 feet.

7708-15 NE (1) - About 0.2 mile downstrean of state hishwas bridse over the Enslish River" about 500 ft west alons torn wr treck from an abandoned and dilaradated railroad bridse over the Enslish Fiver in the base of a train tor rake polet rajl roed spike.

Elev. 663.70 feet. 
7708-15 NW (1) - About 2.5 miles west of Kalona, at intersection of nishwas 22 and north-south county roads 106 feet north and 30 feet west of intersection, a standard USGS tablet, 94EK1969.

Elev. 663.038 feet.

7708-17 NW (1) - About 4.5 miles west of Kalona, at a T-road worth, 65 feet west and 33 feet south, railroad spike in base of power pole.

Elev. 770.28 feet.

7709-03 SW (1) - About 3 miles northwest of Wellmarn, at hishway W21 bridse over Enslish River, on risht dowristream winswall curb, a chiseled sauare, TBM $\mathrm{E}-17$.

Elev, 691.70 feet.

7709-03 SW (2) -- (REFERENCE FOINT) About 3 miles northwest of Wellman, at hishway W21 bridse over Enslish River, on tof of 21 st downstream suardrail post from risht end of bridse, a chiseled arrow.

Elev, 694.32 feet.

7709-07 NW (1) - About 5.5 miles west of Wellman, at old pony truss bridse over South English River, on tor of risht downstream fier, on a bolt, 3 chiseled cross.

Elev, 696.46 feet.

7709-07 NW (2) - (REFERENCE FOINT) About $5+5$ miles west of Wellman, at old pons truss bridse over South Enslish Fiver, on center downstream vertical truss menber, a filed arrow.

Elev, 702.16 feet.

7709-07 SW (1) - About 5.5 miles northwest of Wellman, at junction of county roads, 136 feet north of T-road west, 14 feet south and 30 feet east of a east drivewas, a starderd tablet stamed 6 WEK 1969.

Elev. 792,938 feet.

7709-09 SE (1) - About 3 miles northwest of Wellmany at intersection of hishway 21 and county road, in center of intersection, a hishwas conmission FIUS: UE6D.

Elev. 760.50 feet.

7709-12 SE (1) - About 1 mile north of Wellmang at intersection of hishway 114 and counts road, in center of intersection, a hishwas comnission glus, UE7II.

Elev. 762.320 feet.

7710-08 NW (1) - About 4 miles northeast of South Enslish, between T-rozd north and T-road south of east-west county road, 33 feet south and 228 feet west of a farm drive, 112 feet northwest of northwest corner of a larse house, 11 feet north of a fence corner rost, a standard tablet stamped 1 IUWE 1964".

Elev. 831.946 feet.

7710-08 SE (1) - About 4 miles northeast of South Enslish, across road from Russel Bucher farm (1979), 24 feet east of road, in base of power fole, spike and collar.

Elev. 813.90 feet.

7710-11 SE (1) - About 2 miles northeast of Kinross at county road bridse over South Enslish River, at risht upstream bridse seat, on tor of a 1 inch bolt, a chiseled cross.

Elev, 704.90 feet.

7710-11 SE (2) - (REFERENCE FOINT) hbout 2 miles northeast of Kinross, at county road bridse over South Enslish River, at center and tof of downstream side of pons truss bridse, about 5 feet above bridse floor, a filed arrow.

Elev. 712.14 feet

7710-12. NW (1) - About 3 miles northeast of Kinross, at counity road bridse over a small creek, on tof of risht upstream winswall supfort post (12 inch dia, b, a copfer nail and washer, UE: 2 LIWE III.

Elev. 706.680 feet. 


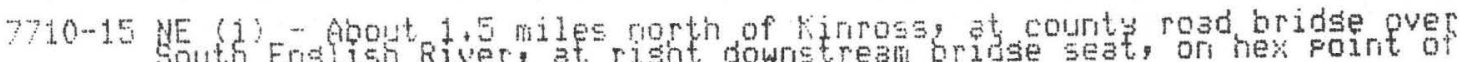
binch nut: 2 chisel ierls.

$$
\text { Elev, } 711.10 \text { feet. }
$$

7710-15 HE (2) - (REFERENCE FOIPT) About 1.5 miles north of Kinross? at county roed bridse over Gouth Enslish Fiverg on first downstrean vertical bridse memoer from risht end bridsen a filed arrow.

Elev; 718.28 feet.

7710-15 GE (1) - About 1. mile north of Kinross? near center of west-south bend in road, on top of southwest hearwall of concrete box culvert, a chiseled sware next to IHC lus; UE 2 [WEE A.

Elev. 743.980 peet.

7710-17 ME (1) - About 3.5 miles northesst of South Enslish, at counts road bridse over South Enslish River, on downstrean curb at risht end of bridse, $\exists$ chiseled square. TEM E24.

Elev, $725+92$ feet.

7710-17 NE (2) - (REFEFENCE FOINT) About $3+5$ miles northeast of South Enslish et counte roen bridse over South Enslish Fiver, on tor of 15 th downstrean suaroreil post prom risht end of bridse, a chiseled arrow.

Elev. 727.95 feet.

7711-13 He (1) - About 2.5 miles northesst of South Enslich at countes road bridse over the South Eriglish Fivers on $a$ sufport file for the risht

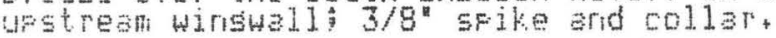

Elev. 727.40 feet.

7711-14 S4 (1) - About 1,5 miles rorth of South Enslish on county T-roed west, or bridse over a smell creel. on risht downstream end of bridse on wooren piers a chiseled cross on iron Fin.

Elev: 737.22 feet.

7711-14 SE (1) - hoout 1 fille north of South Enslish, at hishwas 149 bridse over South Enslish Fiver, on risht downstrean winswall, a hishway compission Flus.

Elev: 741.12 feet,

7711-14 SE (2) - (FEFEFENCE FOINT) About 1 mile north of South Enslish at hishwas 149 bridge over South Enslish Fiver, at downstream side bridse, at. 2nd vertical bridse member froh risht, on tof suardrail suprort, a chiseled arrow.

Elev, 744.18 feet.

7711-15 S4 (1) - About 1.5 miles northwest of South Erslish at railroad bridse over South Enslish Fiver, on risht downstrean abutment, a standerd teblet stamred 'II $861934^{\mathrm{m}}$,

Elev. 746.212 feet:

7714-18 Nh (1) - (REFERENCE POINT) About 2, miles northesst of South Enslish. at a county road bridse over south Enslish Fiver, or tor of sth dowr strean suardral suffort from risht end of bridseg a chiseled arrow. Elev. 730,74 feet.

$771.19 \mathrm{NW}$ (1) - About 2 miles north of Webster, at counts road bridse over Sout Enslish River, or risht downstream winswall: a chiseled sauere.

Elev, 764.55 feet.

7711-19 NW (2) - (REFERENCE FOJNT) About 2 miles north of Websters at courits road bridse over south Enelish Riverg on tor of 12th downstream suardrail sost frofit risht end of bridse, a chiseled arrow.

Elev. 765.59 feet.

7711-20 1tw (1) - About 1.7 miles north of webster: at small fons truss bridse over South Enslish River, on left downstream end of triss, a chiseled cross on top of a rivet.

Elev, 749.31 feet.

$711-20$ NE (1) -- About 2 riiles northeast of Webster" near a concrete bridse" 200 feet UF stream on left bark, in hase of power poleg a las bolt.

Elev. 743,45 feet. 
7711-20 NE (2) - Abput 2 miles portheast of Webster, 3t a courty rgad bridse

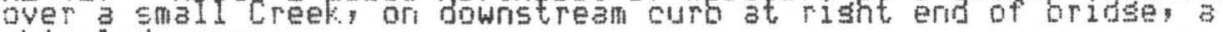
chiseled square.

Elev, 751.36 feet.

7711-20 PEE (3) - About 2 miles northeast of Webster, at county road bridse over South Enslish Riverg on uFstream curb at left end of bridses $a$ chiseled sousre.

Elev. 752.60 feet.

7711-21 NE (1) - About 2.5 miles northeast of Webster, at a concrete railroad bridse over 3 smili Creek, on risht downstream abutment, a chiseled sauare.

Elev. 741.03 feet.

7711-21 NW (1) - (REFERENCE POINT) About 2 miles northezst of Webster, at counts road bridse over South Enslish River, on tof of the 14 th downstrean suardrail post from left abutment, a chiseled arrow.

Elev, $754+51$ feet.

7712-15 SW (1) - (REFERENCE FOINT) About 1.25 wiles north of Keswick at county road bridse over South English River, on the 8th downstream suardrail post from left end of bridse" a chiseled arrow.

Elev. 781.36 feet.

7712-16 SE (1) - About 1.25 miles north of keswick, at county road bridse over South Enslish Riverf on upstrean curb at risht end bridse: a chiseled झauare.

Elev. 781.36 feet.

7712-16 NE (1) - About 1,75 miles north of Keswick, 42 feet west and 77 feet south of drive to Bowman farm (1979), in base of fower pole a bod spike. UE: 24 ILWE B.

Elev. 821.560 feet.

7712-16 54 (1) - About 1.5 miles northwest of keswick, at county road bridse over South Enslish River, at risht end of downstrean truss: a chiseled cross on truss bolt.

Elev. $782+14$ feet.

7712-16 SW (2) - (REFERENCE FOIMT) About 1.5 miles northwest of Keswick, 3t county rozd bridse over South Enslish River, on too of pons truss, aver 3 rd vertical member from risht, a chiseled ofen square,

Elev. 788.17 feet.

7712-16 54 (3) - About 1.5 miles nortinwest of Keswick, st counts roed bridse over South Enslish Fiver, on risht downstream bridse seat, 2 chisel marks on bolt (found loose), $1974 \mathrm{BM}$.

Elev. 779.31 feet.

7712-17 SW (1) - (REFERENCE POINT) About 2.5 miles nortinwest of Keswick, st county road bridse over South Enslish River, at downstream center cross member of truss, on tif of beveled end of ansle irons $a$ chiseled arrow:

Elev, 788.21 feet.

7712-18 NW (1) - (REFERENCE FOINT) About 3.5 miles northwest of Kesuick, at county road bridse over South Enslish River, on tor of 12 th downstreani suardrail post from risht end of bridses a chiseled arrow.

Elev. 798.30 peet.

7712-18 SE (1) - About 2.5 miles northwest of Keswick, at county road bridse over South Enslish River, at left upstrean bridse seat, 3 chiseled square at end of an I-beam.

Elev, 783.73 feet.

7712-23 NE (1) - About 2.5 niles northwest of Webster: at courits road bridse over South Enslish River, on risht upstream winspost, a chiseled souare.

Elev. 770,45 feet.

7712-24 NW (1) - (REFERENCE FOINT) About 2.5 miles northwest of Webster, at county rozd bridge over South Enslish fiver, on 14th downstrean suardrail fost from risht end of bridsen a chiseled arrow.

Elev, 770.54 feet. 
7713-05 SE (1) - Apoyt 1 mide northezst of Gioson at tof of erominerit hill Torisinal E-W road returned to cultuation a acessible from west by a dirt road almost leading to monument between 2 wooden fosts, 30 feet north of esst-west fence, a stendard tablet stamped "ET 14 DHE $1964 \%$.

Elev. 890.779 feet.

$7713-05 \mathrm{NW}$ (1) - About 1.8 miles north of Gibson: at county road bridge over South Enslish kiver, at dowrstream end of risht file Fier, on dowrstream end of streamard L-iron a chiseled square.

Elev, 815,13 feet.

7713-05 NW (2) - (FEFERENCE FOINT) About 1.8 miles north of biosony at counts road bridse over South Enslish Fiver, on tof of 7 th downstrean Suardrail post from risht end bridse, a chiseled arrow.

Elev, 820.98 feet.

7713-06 SW (1) - About 1.0 mile northwest of Gioson alone E-W counts roed, afrok 0.1 nile east of county line, $32 \mathrm{ft}$, north of road and 18 Pt. west of drive to a farm 2 ft. south of a white fences $4 \mathrm{ft}$ : south of a wower pole" a staridard bablet stamped "28 luE $1964^{*}$.

Elev; 895.977 feet.

7713-08 ME (1) - About 1 mile northezst of Gibson at counts posd hridse over South Enslish Fiver, in suffort pile of risht upstrean winswall, reilrobo srike,

E1ev. 805.19 feet,

77.3-08 Wh (A) -... About 1 mile north of Gibson at crossmods of courit's roads (T-road west), 30 feet south and $34-f e e t$ east, in bese of fower fole. a railrogo spike.

Elev. 881,43 feet.

7713-09 Nh (1) - (REFERENCE FOINT) About 1 mile northesst of Gibsons at counts roed bridse over South Enslish Fiver, at center of cownstream edse of concrete slab, a chiseled arrow.

Elev, 806,62 feet.

$7713-09$ SE (1) - About 2.5 miles northwest of Thornoursy at hishwas 21 bridse over South Erislish Fiver, on left ufstream winswll, a defartment of trensportation flus.

Elev: 804.46 feet.

$7713-10$ NW (1) - About 3 miles north of Thornburs, at intersection of hishwas 21 and county road. 41 feet soutin and 58 feet east, 5 feet north of a Fower pole and 4 feet northwest of a comer post. a standard tablet stamed 27 IWE 1964 :

Elev, 885,357 feet.

7713-10 54 (1) - (FEFEFENCE FOIHT) About 2.5 miles northwest of Thormburs, at hidnwey 21 bridge over South English Rivers on top of gth downstream concrete suerdrail fost from left end of bridsen a chiseled ofen sauare. Elev, $807+50$ feet.

7713-12 54 (1) - About 4.5 miles northwest of keswicks at county road bridse over South Enslish Fiver on downstream curb at left end of bridsey a chistied square.

Elev. 794.94 feet.

7713-12 DW (2) - (REFEFENCE POINT) About 4.5 miles northwest of Keswick, at county road bridse over South English River, on tof of 7 th downstream suerdrail fost from left end of oridgen a chiseled arrow.

Elev, 796.84 feet.

$7713-13$ NE (1) - About 3.5 miles morthwest of keswiek at counts road bridse over south Enslish Fiver, at risht end of bridse on upstream curb. $a$ chiseied squere.

Elev, 796.10 feet.

7744-01. Wh (1) - (REFERENCE FOINT) About 2 wiles east of Earmes cits at a rorth-south counts road over the South Enslish Fiver, on ath dowr stream suardrail Fost from left end bridse, a chiseled arrow.

Elev. 832.09 feet. 


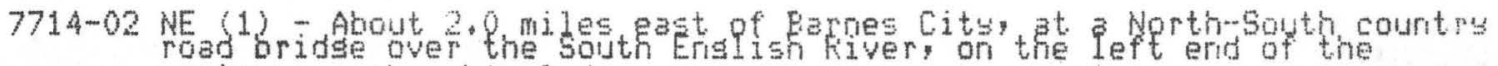
ufstream curby chiseled sauare.

Elev. 829.96 feet.

7714-02 NE (2) - (REFEFENCE FOINT) About 1.8 miles esst of Bames Cits, at east-west counts road bridse over South Enslish River, on tof of the 3rd downstrean suardrail fost from risht end of bridge, 3 chiseled arrow.

Elev. 234,18 feet.

7714-12 NW (1) - About 2 miles southeast of Barnes Cits, at T-road north intersection, 29 feet south and 6 feet east, in base of power fole, railroad sFike.

Elev. 901.07 feet.

7809-31 NW (1) - (REFERENCE FOJNT) About 6.5 miles east of North Enslish, at bridge over English River, on suffort for 16th downstream Suardrail. fost from left end of bridse, below level of curb, 2 file marks,

Elev. 705.47 feet.

7810-07 NW (1) - About 4.5 miles north of North Enslish, south of intersection of hishwass 149 and 166 , 41 feet east of hishwas 149 and 13 feet south of drivewas to farm, in power pole, a railroad spike.

Elev; 749,15 feet.

7810-07 SW (1) - (REFERENCE POINT) About 4 miles north of North Enslish at hishwas 149 bridse over the North English Fiver, at 3rd downstrean vertical bridse member from risht end bridse, on tof streamward corren of top suardrail suprort, a chiseled arrow.

Elev. 731,17 feet.

7810-12 SE (1) - About 4 miles north of North Enslish, at hishwas 149 bridae over the North Enslish River, on the usstrean end of the left streanward qier, TBM E-39, a chiseled square.

Elev, 723.05 feet.

7810-20 SE (1) - About 2 miles east of forth Ensilish at county road bridse over North Enslish River, on tof of risht downstrean fier, a chiseled square.

Elev. 710.45 feet.

7810-20 SE (2) - (REFERENCE FOINT) About 2 miles east of North Enslish at counts road bridse over North Enslish River, on tof of ufFer suard-rail support at center downstresm vertical bridse member, an arrow of punched dots.

Elev, 716.96 feet.

7810-20 Su (1) - About 2.5 miles northeast of North Enslish, at railroad bridse over North Enslish River, on Ist downstream bolt from left end of bridse UE 39 C IHB.

Elev: 716.870 feet.

7810-20 NW (1) - About 3 miles northeast of North Enslish, at county road bridse over North Enslish Fiver, on risht downstrean end of curb, a chiseled sQuere, TEM E 38 .

Elev. 720.64 feet.

7810-20 NW (2) - (REFERENCE FOINT) About 3 miles northeast of North Enslish, at. counts road bridse over North Enslish River, on tor of 17 th downstream suardrail fost from risht end of bridse, a chiseled arrow.

Elev, 722.85 feet.

7810-27 SE (1) - About 4 miles east of North Enslish, at hishway F67 oridse over North Enslish River, on left downstream winswall, bolt enbedded in concrete.

Elev. $710+91$ feet.

7810-27 SE (2) - (REFERENCE FOINT) About 4 miles east of North Enslish at hishwas F67 bridge over North Enslish River, on tor of 16 th downstream suaroreil post from left end of bridse, a chiseled arrow.

Elev, 712,86 feet. 


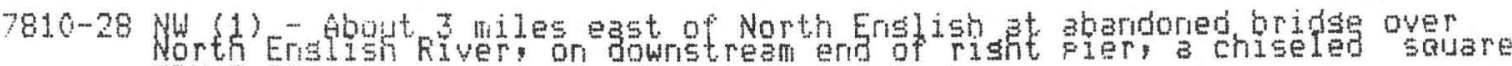
TEM E-29.

E]ev. 708.44 feet:

7810-28 NH (2) - (FEFERENCE FOINT) About 3 miles east of North Enslish at abanioned bridse over North Enslish Fiver, on bownstream suardrail 6 foot streamiari from 2 nd vertical bridse member from left ent of oridse. 2 file maks. RF $48-9$.

Elev. 714.96 feet.

7810-28 NE (1) - About 3.5 miles esst of North Enslish, at end of abandoned roads on tor center of south headwall of a 5 foot culvert, a chiseled sauare,

Elev. 705.74 feet:

7910-30 NW (1) - About 1.5 wiles north of North Enslish, at state hishwas 149 bridse over the North Enslish River, on the left end of the downstrean truss, on downstreen - lendwerd rivet chiseled cross.

Elev. 726.57 feet.

7810-30 Hu (2) - (FEFEFENCE FOINT) About 1 . 5 miles north of North Enslish at State Hishwas 149 bridse over North English River, five feet left of 2nd downstreami vertical bridse member, on tof of suardrail, a chiseled arrow.

Elev. 730.44 feet.

7810-30 NE (1) - About 3.0 miles northeast of North Enslishs at the C. M. Ct. $F$, F, railroad bridse over the Middle Enslish fiver, on the downtream end of the risht abutment' a standard tablet stanced ' $185^{\prime \prime}$.

E] Ev: $725+645$ feet.

7810-30 NE $(2)$ - About 3 miles northeast of North Enslish at a small country rosd bridse over the Middle Enslish Fiver, on the risht end of the downstream truss, on tor of a riveth chiseled cross.

Elev. 716,40 feet.

7310-30 NE (3) - (REFEFENCE FOINT) About 3 miles northeast of North Enslish? at a small country road bridse over the Middle English River, on the 19t downstrean vertical bridse merber from the risht end of bridses a filed arrow.

Elev, 721,10 feet.

7310-30 NE (1) -- About 6.5 miles East of North Enslish at bridse over Enslish River, on risht upstresm winswally a chiseled cross.

Elev, 704.91 feet.

7811-01 34 (1) - (FEFEFENCE FOINT) About 5 miles north of North Enslish, at hishws FS2 bridse over the North Enslish Fivery on tof of 17 th downstreen suardraj. post from risht end of bridse, a chiseled arrow.

Elev. 733.39 feet.

7911-02 94 (1) - About 5 miles north of North Erislish, at hashwas F52 bridse Over a small Creek, on tof of curb at risht uFstream end of bridse, i chiseled sausre.

Elev, 731.75 feet.

7e11-02 SE (1) - About 5 miles north of North Enslish at hishwas F52 bridse over the North Enslish Fiver, on tor of curb at left upstrean end of bridse, a chiseled sourre. TEM E-40.

Elev. 731.09 feet.

7811-03 NH (1) - About 6 miles northwest of North Enslish, at counte road bridse over North Enslish River, on left downstream curb, a chiseled sausrea NE $21 \mathrm{~B}$ CDL.

Elev. 739.950 feet.

7911-03 NW (2) -.. (REFEFENCE POIRT) About b miles northwest of North Enslish, at county road bridse over North Enslish Rivery on 17 th downstream guardrail post from left end of bridses a chiseled arrow.

Elev: 741.98 feet. 


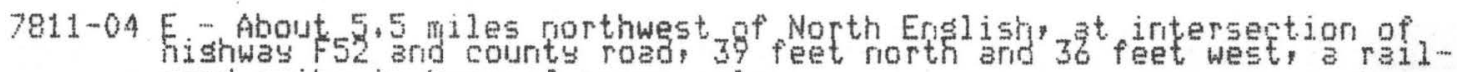
road spike in bese of power pole.

Elev, 838,46 feet.

7811-10 su (1) - About 4.5 miles northwest of North Enslish, near a T-rd west, $200 \mathrm{ft}$, north and $30 \mathrm{ft}$. E, and $15 \mathrm{ft}$. south of a private drive; a standard tablet, stamped " 22 CDL 1966 "

Elev. 854,486 feet:

7811-20 NW (1) - About 5.0 miles northwest of North Enslish, st counts hishwas U52 bridse over the Middle English Fiver, on tof of 1st downstrean suardrail post from left end of bridsei two chiseled marks.

Elev. 760,98 feet.

7811-20 Nu (2) - (REFERENCE FOINT) About 5 miles northwest of North Enslish, at county road U52 bridse over Middle Enslish Fiver, on toF of 10 th downstream suardrail rost from left end of bridse: a chiseled arrow.

Elev. 761,11 feet.

7811-22 NW (1) - About 3.5 miles northwest of Horth Enslish, at a "culverttupe bridse over the Middle Enslish River, on tor of the left end of the downstream suardrail chiseled sauare.

Elev. 743.38 feet.

7811-22 NW (2) - (REFERENCE FOINT) About 3.5 miles northwest of North Enslishs at a culvert-type bridse over iddle Enslish River, on downstream edse of concrete suardrail, about 6 feet from risht end, a chiseled square.

Elev. $743+29$ peet.

7811-22 Nu (3) - About 3 miles northwest of North Enslish, in southeast corner of intersection of countrs crossrosds punched hole in $3 \mathrm{ft}$. metal culvert.

Elev. 775,15 feet.

7811-25 NW (1) - About 1,75 miles north of North Enslish, at a country road bridse over the Middle Enslish Fiver, on the left end of the downstream truss, on tof of a rivet chiseled cross.

Elev: 733.36 feet.

7811-25 NW (2) - (REFERENCE POINT) About 1.8 miles north of North Enslish, zt counts road bridse over Middle Enslish River, at center downstream vertical bridse member, on tor of suardrail suprort, a chiseled arrow.

Elev: 737,84 feet.

7812-04 NE (1) - About 5 miles northwest of Millersburs, at a country road bridse over the North English River, on the risht end of the downstream truss, on tof of $z$ rivet; chiseled cross.

Elev, 767,60 peet.

7812-04 NE (2) - (REFERENCE POINT) About 5 miles northwest of Millersburs at. counts road bridse over North Enslish Rivery on the 2 nd downstream vertical bridse truss member from risht end of bridse? $a$ chiseled arrow.

$$
\text { Elev; } 771.98 \text { feet. }
$$

7812-04 SE (1) - About 4.5 miles northwest of Millersburs, $485 \mathrm{ft}$. E of T-ro north. 34 ftw north of road, at erest in fence line, $1 \mathrm{ft}$ south of E-W fences of ft. SE of witriess post, a standard tablet stamped' 22 IWWE $1966869 \%$

Elev. 868.650 feet.

7812-05 SW (1) - About 4 miles east of Deer River, at county hishway U38 bridse over lleep River, on risht downstream bridse seat' two chiseled marks.

Elev. 777.45 feet.

7812-05 SW (2) - (REFERENCE FOINT) About 4 miles east of Deer River, at counts road U38 bridse over Deef River, on tof of the 9 th downstream suardrail post from the risht end of bridse, a chiseled arrow.

Elev. 783.41 feet. 
7812-05 5W (3) - About $4+5$ Biles east of leer River at an L-chrve in county roag; on south end of $3 \mathrm{ft}$. metel fife culvertif punched hole.

Elev. 768.80 feet.

7812-06 5W (1) - About 3 miles east of lleef fiver, at a county rozd bridse over the llees River, on the left end of the downstrean truss? on downstrean laridward-most rivet chiseled cross.

Elev. 789.39 feet.

7812-06 SW (2) - (FEFERENCE FOINT) About 3 miles east of Ileef fiver, at counts road bridge over Ilees River, on the left upstream edse of the center downstrean vertical bridse member" 5 inches above suardrail" a chiseled notch.

Elev, 793.67 feet.

7812-14 SW (1) - About 8.0 miles northwest of North Enslish, on east side of junction of $N-S$ country road and $T-r d$. Westy in base of a rower Folei a railroad sfike.

Elev, 859.33 feet.

7812-15 5w (1) - About 9.0 miles northwest of North Enslish, at a countrs road bridge over $z$ small creet, on the risht upstrean winswall chiseled sauare.

Elev, 793.54 feet.

7812-22 NW (1) - About 9.0 miles northwest of North English at a country rosd bridse over the Middle Enslish Fiver, on the left downstream winswall' a standard tablet stamped "23 DWE $1966^{\circ}$

Elev: 789.798 feet.

7812-22 NW (2) - (FEFEFEHCE FOINT) About 9 miles northwest of North Enslish, at a county road oridse over Middle Enelish River, on tor of the Ath downstream suardrail post from left end of bridsen a filed arrow:

Elev. 791.82 feet.

7812-23 NW (1) - About 3.0 miles northwest of North Enslish at a country rosd bridse over the Midole Enslish River, on the left downstream winguslly chiseled sauare.

Elev. 784.09 feet.

7812-23 NW (2) - (FEFERENCE FOINT) About 8 miles rorthwest of North Enslish at county road bridse over the Middle Enslish Fiver, on tor of Sth downstream suardrail cost from risht end of bridses 3 chis eled saure.

Elev: 785.70 peet.

$7812-24$ SW (1) About 7.0 miles ronthwest of North Enslish at a countrs road oridse over the Middle English Fiver, on the left downstreani batter Fost at suardrail level" on a rivet chiseled cross.

Elev. 773.09 feet.

7812-24 SW (2) - (REFERENCE FOINT) Aoout 7 miles northwest of North Enslish: at county road bridse over Middle Enslish fivery on the 1 t downstrean vertical bridse menber from the risht end of bridsea $a$ filed arrout

Elev. 773,77 feet.

7813-01 SW (1) - About 2 miles east of leef River at a counts road bridse over Ileep Fivery on the left downstream batter rost at suardrail level, on e rivet; chiseled cross.

Elev. 795.05 feet;

7813-01. SW (2) - (FEFEFENCE FOINT) About 2 miles east of lleep River, at a county road bridse over deer River, on the center downstrean vertical bridse menbery a chiseled arrow.

Elev. 795.51. feet.

7814-34 NL (1) - About 1 mile north of Eernes Citsy at CSG site on county roed oridse over South Enslish River, on risht dowrstream winswall chiseled sauare.

Elev: 844,72 feet. 
Introduction . . . . . . . . . . . . . . . Page
Purpose and scope . . . . . . . . . . . . . . . . . . . 1
Acknowledgements 1

Basin description. . . . . . . . . . . . . . . 2

Flood history .................. 2

Hydrologic data. . . . . . . . . . . . . 5

Flood frequencies. . . . . . . . . . . . . 7

Flood profiles .................. 9

Discussion ................. . . 10

References ................... 11

Gaging-station records . . . . . . . . . . 25

05455140 North English River near Montezuma • . • 27

05455150 North English River near Montezuma • • . 28

05455200 North Eng1ish River near Guernsey . . . . 30

05455210 North English River at Guernsey . . . . 32

05455230 Deep River at Deep River . . . . . . 33

05455280 South English River trib. nr Barnes City. . 34

05455300 South English River near Barnes City. . . 36

05455350 South English River trib. no. 2 nr Montezuma 38

05455500 English River at Kalona ........ 40

05455550 Bulgers Run near Riverside ....... 45

Temporary bench marks ... . . . . . . . . 47 
7814-35 5W (1) - Abgut 1 mile northwest of Eerres city at county road brjdse over South Enslish River, on risht downstream bank, in a power potey a spike and collart

Elev. 833.25 feet.

7814-35 SW (2) - About 1 mile northeast of Barres City at a courity road bridse over the South Enslish River, on the risht end of the downstream curb chiseled sauare.

Elev. 837.44 feet.

7814-35 5W (3) - (REFEFENCE FOINT) About 1 mile northeast of Barnes cits? at county road bridse over South Enslish fiver, on tof of the 4 th downstream suardrail post from risht end bridsey a chiseled arrow. Elev, 839,59 feet.

7814-35 SE (1) - About 1,75 miles east of Barnes City, at east-west country road bridse over the South Enslish River, on the risht end of the upstrean curb; chiseled sauare.

Elev, 832.02 feet.

7911-32 ME (1) - About 2.5 miles north of Millersburs, at crossroads of county roads near center of section, in northeast correr of intersection, in power poles a railroad saike.

Elev, 775.90 feet.

7911-32 SE (1) - About 2 miles north of Millersburs, at county road US2 bridse over North Enslish River, on downstream curb at left end of bridse, e chiseled cross.

Elev. 745.54 feet.

7911-32 SE (2) - (REFERENCE FOINT) About 2 miles north of Millersburs, at county road U52 bridge over North Enslish River' on 12 th downstream suardrail post from right end of bridse, a chiseled arrow.

Elev, $747+84$ feet.

7911-34 NW (1) - About 7 miles northwest of North Enslish, at T-road west near auarter corner of section 34,39 feet north and 32 feet east, of intersection, in base of power pole? a ralroad soike.

Elev, 745.08 feet.

7912-19 NW (1) - About 3 miles east of Euemnes, at a bridse over the North Enslish River, on the risht upstrean winswall; a chiseled sauare.

Elev. 790.55 feet.

7912-19 NW (2) - (REFERENCE POINT) About 3 miles east of Guemsey, at county road bridse over North Enslish River, at the center downstrean vertical bridse member, on tof of suardrail suffort, a chiseled arrow.

Elev, 793.55 feet;

$7912-2056$ (1) - About 7.5 miles nortiowest of Millersburs at counts hishway bridse over the North Erislish River, on the risht dowristream winswall chiseled cross.

Elev, 785.75 feet.

7912-20 SW (2) - (REFERENCE FOINT) About 7,5 miles northwest of Millersburs; at county hishway bridse over North Enslish River, on top of 12 th dowristrean suardrail post from risht end bridse, a chiseled arrow.

Elev. $788+16$ feet.

7912-26 SE (1) - About 4 miles northwest of Millersburs, at T-road north of offset counts crossroads; 50 feet south and 27 feet west in base of rower fole: a 5 Fike and collar.

Elev. 761.24 feet.

7912-27 SE (1) -- About 4.5 miles northwest of Millersburg, at T-road west at southeast corner of section, at bridse over small Creek, on left upstrean winswall file, a railroad spike.

Elev. 765.46 feet.

7912-28 SE (1) - About 6 miles northwest of Millersburs, 3t St. John's Lutheran cenetery, at center of 2 nd ster from botton of main sate, a chiseled cross, UE 21A [UWE.

Elev. 845.230 feet. 
$7912-28$ gw (1) - About 6 miles northwest of Millersours, at St John's and $48 \mathrm{ft}$. E of $T-\mathrm{ro} W$. $\mathrm{ft}$. NE of 3 gower gole? $1 \mathrm{ft}$. West of $a$ fence and $5 \mathrm{ft}$. north of a corner post; a standard tablet stamped "21 INB 1966859 ".

Elev, 859.512 feet.

7912-29 SE (1) - About 6.5 miles northwest of Millersburgy at a county roed oridse over the North Enslish Fiver: on tor of the left down' strean wirispost. chiseled sauere.

Elev, 783.55 feet.

7912-29 SE (2) - (REFERENCE FOINT) About 6.5 miles northwest of Millersburs, et county road oridse over North English Fiver, on tof of 12 th downstrean suardraji post fron left end of bridse, a chiseled arrow.

Elev. 783.42 feet.

$7912-29 \mathrm{NW}$ (1) - About 7.5 miles northwest of Millersburs, in northesst corner of intersection at county hishwse V38 and an E-W country roedz railroed saile in bese of a power role.

Elew: 820.28 feet.

7912-34 SE (1) - About 4 miles northwest of Millersours at county road bridge over North English River, on risht upstrean end of curb, a chiseled cross.

Elev. 763.27 feet.

7912-35 SW (1) - (FEFEFENCE FOINT) About 4 miles northwest of Millersburs, at counte road bridse over North Enslish River; on 14th downstrean guardrail supgort from risht end of bridses a chiseled arrow. Elev. 765.69 feet.

7912-35 NE (1) - About 3.5 miles northwest of Millersburs, at counts roed bridse over North Enslish River, on left upstrean pier, on edse of 12 inch C-irong a chiseled squere.

Elev: 750.59 feet.

7912-35 NE (2) - (REFERENCE FOINT) About 3.5 miles northwest of Millersburs, at county roed bridge over North Enslish River, on center downstream vertical truss member, a chiseled arrow.

Elev, 754.54 feet.

7913-15 SW (1) - About 0.5 mile west of Guernses, in southeast corner of junction of state hishwas 21 and T-rd east, $146 \mathrm{ft}$. south and 122 ft. ezst of junctiong $6 \mathrm{ft}$ north of a corner post, near a witness Fost" a standard tablet stamied "30 [WWB 1966865 ".

Elev. 665.536 feet.

7913-15 SE (1) - At east end of Guernsey, at sutheast end of 3 NW-SE roed leadins out of town just before turnins south, in last power pole alons roars $26 \mathrm{ft}$, northeast of road 3 nd $61 \mathrm{ft}$. northwest of a $\mathrm{Fri}-$ vate drive $5 \mathrm{ft}$, southwest of a right-of-way fencel railroad seike in base of power fole.

Elev. 810.12 feet.

7913-17 SE (1) - About 1.5 miles west of Guernseys at a bridse over a small creek on west les of crossroads on the upstrean end of the left

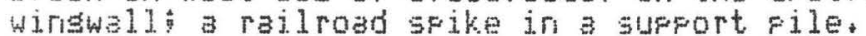

Elev, $808+35$ feet:

7913-17 SE (2) - About 1.5 miles west of Guernsey, at a bridse over the North English River, on the left urstrean bridse seat; a chiseled cross:

Elev. 807.12 feet.

7913-18 SE (1) - About 2.5 miles west of Guernses, at a counts road bridse over North Enslish River, on risht usstream bridse sest; chiseled cross on a 1 inch bolt.

Elev. 813.46 feet. 
7913-18 SW (1) - About 3.5 miles west of Guerrisey, at a county road bridse over the North English River, on the risht end of the downstream truss, chiseled cross on rivet.

Elev. 819.53 feet.

7913-18 SW (2) - (REFERENCE POINT) About 3.5 miles west of Guernses, at. county road oridse over North English River, on the 2 nd downstream vertical bridse member from the left end of oridse, a filed arrow. Elev: 815,36 feet.

7913-21 NE (1) - About 0.75 mile southwest of Guernsess at state hishwas 21 bridse over the North Enslish River, on the risht end of the upstrean curb: chiseled cross, UE: $30 \mathrm{~A}$ DUB.

Elev. 811.040 feet.

7913-21 NW (1) - (FEFEFENCE POINT) About 1.5 miles west of Guernsesy at. bridge over North Enslish River, on the 3 rd vertical bridse member from risht end bridse, a chiseled arrow.

Elev. 811.58 feet.

7913-22 NE (1) - About 0.8 mile southeast of Guerrises, at a county road bridse over the North Enslish River, on the risht end of the urstream truss chiseled cross on bolt.

Elev. 797.24 feet.

7913-23 NW (1) - (REFERENCE FOINT) About 0.8 mile southeast of Guernses, at county road bridse over North Enslish Rivery on the 1st downstream vertical bridse member from risht end of bridse, six inches above suardrail, a chiseled zrrow.

Elev, 801.64 feet.

7913-23 NE (1) - About 1 mile southeast of Guemses, at 3 pons truss bridse over the North Enslish River, on the left end of the downstream trusst a chiseled cross.

Elev. 794.45 feet.

7913-23 NE (2) - (REFERENCE FOINT) About 1 mile southeast of Guernsey, a4, a fory truss bridse over North Enslish River, on risht end of downstream batter post, a chiseled arrow.

Elev, 796.84 feet.

7913-23 NE (3) - (REFERENCE POINT) About 1 mile southeast of Guerrises, at 3 pons truss bridse over North Enslish Fiver, on top and in center of downstream eony truss bridse, a chiseled arrow.

Elev, 800,27 feet.

7913-25 NE (1) - About 2.5 miles southeast of Guernses, at T-rd west on county line, in srasss triansle of junctiong railroad sfike in base of fower pole.

Eley, 854.15 feet.

7914-13 SW (1) - About 4.5 miles west of Guernses, at a county road bridse over the North Enslish River, on the downst ream end of the risht wooden winswall a railrozd spike in a support pile.

Elev. 824.56 feet.

7914-13 SW (2) - (FEFERENCE FOINT) About 4.5 miles west of Guernses; st county road bridse over North English River, on the downstream edse of downstream truss of bridse, at juriction of truss and risht batter post, enclosed by two hacksaw marks; a chiseled arrow.

Elev. 830.62 feet.

7914-14 SW (1) - About 5.5 miles west of Guernses at county hishwas V18 bridse over the North Erislish Fiver on the risht end of the downstream curb' chiseled sauare.

Elev, 834.61 feet.

7914-14 SW (2) - (REFERENCE FOINT) About 5.5 miles west of Guernses? at county hishway V18 bridse over North Enslish River, on top of the loth downstream suardrail post from risht end of bridses a chiseled arrow.

Elev. 835.77 feet. 
7914-16 GE (1) - About 7 miles west of Guernses, ir northezst correr of intersection of courity roads,
sike.
Elev, 867.73 feet.

7914-21 ME (1) - About 7 miles west of Guernses, zt a county road bridse over the North Enslish Fiver, on the downstream end of the left abutment wall chiseled sevare.

Elev. 838.31 feet.

7914-21 NE (2) - (FEFEFENCE FOINT) About 7 miles west of Guennses, at county road bridse over the North Ensilsh Fiver, on to of dowrstreari truss of fons truss bridse: over the 1 t vertical menber from left end of bridses a chiseled arrow.

Elev. 843.51 feet. 
Figure 1. Map of the English River basin, Iowa . . . . . 3 Page

2. Graph of annual peak discharges for English River at Kalona gaging station.......... 4

3. Graph of regional 100-year flood discharge versus drainage area for streams in the English River basin ............. . . 8

4-6 English River profiles . . . . . . . . 13-15

7-9 North English River profiles . . . . . . 16-18

10-12 South English River profiles . . . . . . . 19-21

13 Middle English River profiles . . . . . . 22

14 Deep River Profiles . . . . . . . . . 23

TABLES

Table Factors for converting inch-pound units to International System units (SI) . . . . . . V V

1. Maximum flood peaks at gaging stations in the English River Basin. . . . . . . . . 6

2. Discharge and frequency of flood flows for continuous-record gaging station in the English River basin 
FACTORS FOR CONVERTING INCH-POUND UNITS TO INTERNATIONAL SYSTEM UNITS (SI)

The following factors may be used to convert the inch-pound units published herein to the International System of Units (SI)

Multiply inch-pound units

inches (in)

feet (ft)

miles (mi)

acres

square miles $\left(\mathrm{mi}^{2}\right)$
By

-Length-

$$
\begin{aligned}
& 25.4 \\
& .3048 \\
& 1.609
\end{aligned}
$$

-Area-

4,047

2.590

-Volume-

cubic feet $\left(\mathrm{ft}^{3}\right)$

cubic feet per second-day

( $\left.\mathrm{ft}^{3} / \mathrm{s}-\mathrm{day}\right)$

acre-feet (acre-ft)

$2,447^{0.02832}$

1,233

-Flow-

cubic feet per second

$\left(\mathrm{ft}^{3} / \mathrm{s}\right)$
To obtain SI units

millimeters (mm)

meters (m)

kilometers $(\mathrm{km})$

square meters $\left(\mathrm{m}^{2}\right)$

Square kilometers $\left(\mathrm{km}^{2}\right)$ 



\title{
PLOODS IN THE ENGLISH RIVER BASIN, IOHA
}

by

\author{
A.J. Heinitz and D. R. Riddle
}

\section{IXTRODUCXION}

Purpose and Scope

Information describing floods is essential for proper planning, design, and operation of bridges and other structures on or over streas and their flood plains. This report provides information on flood stages and discharges, flood magnitude and frequency, bench wark data, and flood profiles for the English River and some of its tributaries. It covers the Bnglish River, the North English River to near Guernsey, the south Baglish River to Barnes City and the lower reaches of the Hiddle English and Deep Rivers.

\section{Acknowledgments}

This report is the tenth in a series prepared in cooperation with the Highway Research Board, Highway Division, Iowa Department of Transportation. Various Pederal, state, and local agencies cooperated in the collection of the streanflow records used in this report, acknowledgaent of wich is contained in the annual streamflow reports of the 0.5 . Geological survey. 
The Bnglish River is a tributary to the Iowa River in southeastern Iowa and enters the Iowa River about 10 iles south of Iowa City (fig. 1). The basin covers 638 square iles and includes parts of 6 counties. Land use in the basin is predominanty agricultural with some livestock operations.

Hormal anual precipitation $(1941-70)$ is about 33 inches in the basin. Average annual ranoff is frow 8 to 9 inches.

\section{FLOOD HISTORY}

Recording of flood peaks in the anglish River basin began in 1939 uhen a stream-gaging station was established at Kalona. The historical flood of 1930 was documented from information supplied by local residents. A list of the gaging stations in the basin giving the period of flood record and aximu flood for each station is contained in table 1. 


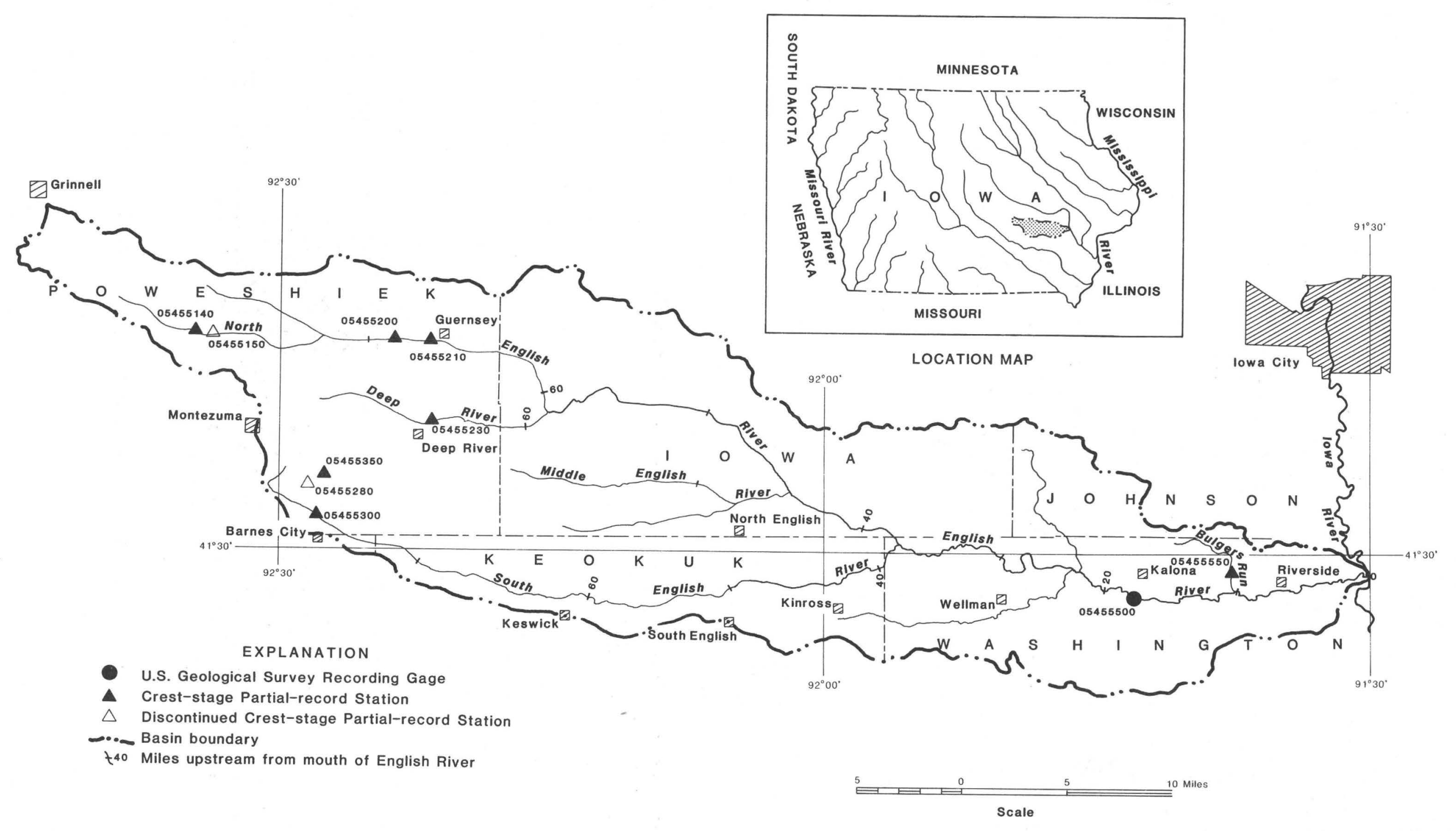

Figure 1. English River basin. 
A graph of the annual peak flood discharges for the gaging station on the English River at kalona is shown in figure 2. This graph depicts the years in which the greater floods occurred at the station. Among these are the floods of $1930,1960,1965$ and 1974 .

The 1974 flood is the 4 th greatest recorded on the English River at Kalona. Tuo of the floods (1930 and 1960) exceeded the 1974 flood peak discharge by only 100 cubic feet per second.

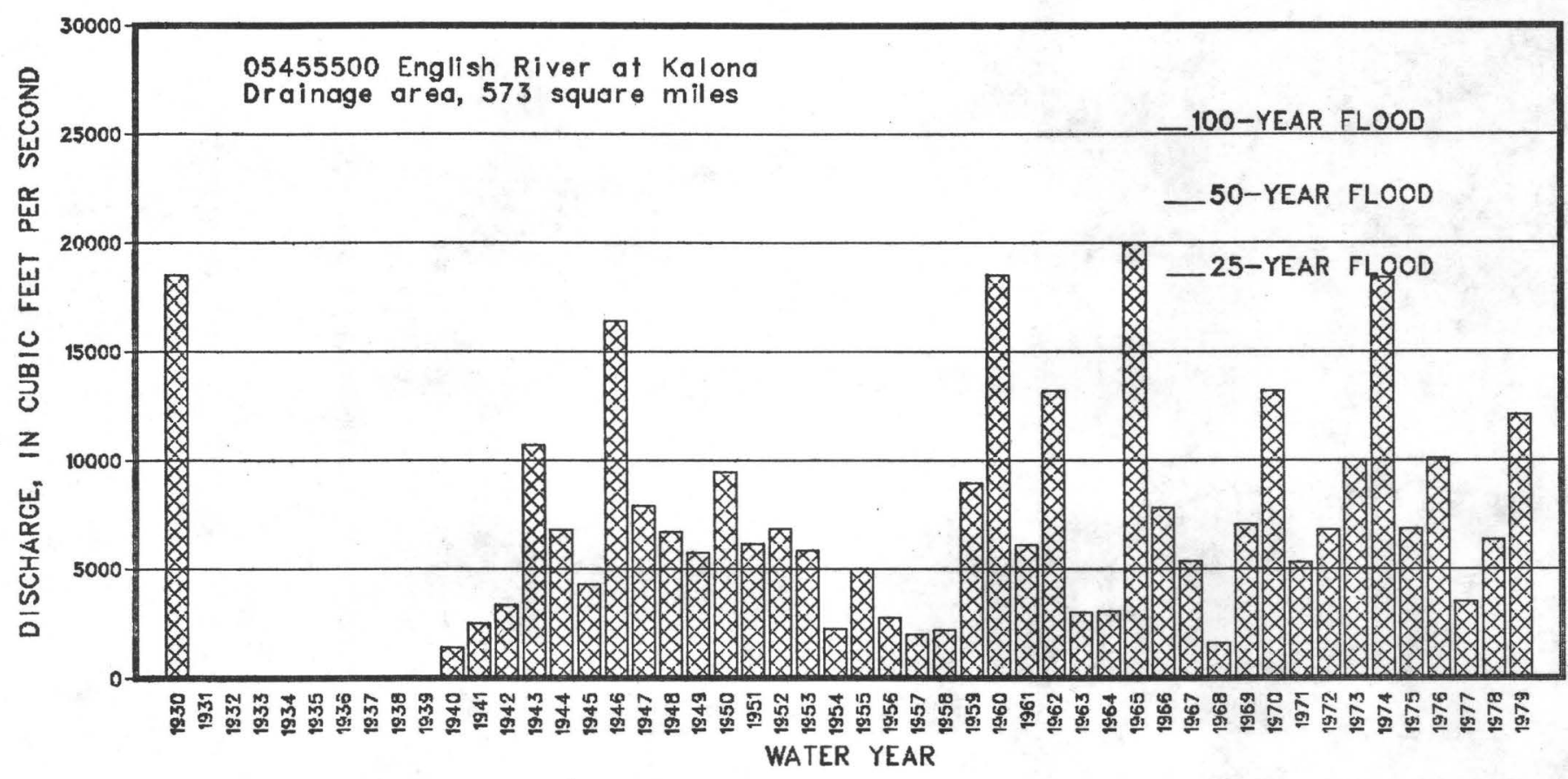

Figure 2. Annual peak discharges for period of record for English River at Kalona gaging station. 
Gaging-station records provide the most useful data needed for analyzing and understanding the flood bydrology of a river basin. Flood information is obtained fro data collected at stream-gaging stations where a continuous record of streanflow is obtained, and from crest-stage partial-record stations wich provide flood-peak data above preselected levels. The gaging stations in the English River basin are shown in figure 1 and table 1.

The gaging station at Kalona, 05455500, is the only continuous-record station in the basin; the remainder of the stations are crest-stage partial-record gages. Discharge records for all the stations are published in the annual streanflow reports of the 0.S. Geological survey (See References). The data on flood-peak stages and discharges fro: these records were compiled by Lara (1976). Those conpilations have been updated and are published in the section on Gaging-station Records.

The derivation of discharge records at a gaging station depends basically upon the development of a relationship between water-surface eleyations (stages) and the corresponding flow rates. The highwater portion of these stagedischarge relationships, or rating curves as they are sometiwes called, tends to be relatively stable if the channel downstrean from a gaging site is not changed and rearins 
Table 1.--Maximum flood peaks at gaging stations in the English River basin, Iowa

\begin{tabular}{|c|c|c|c|c|c|c|c|}
\hline \multirow[b]{2}{*}{$\begin{array}{l}\text { Station } \\
\text { number }\end{array}$} & \multirow[b]{2}{*}{ Gaging Station } & \multirow[b]{2}{*}{$\begin{array}{l}\text { Period } \\
\text { of flood } \\
\text { record }\end{array}$} & \multirow[b]{2}{*}{$\begin{array}{l}\text { Drainage } \\
\text { area } \\
\left(m i^{2}\right)\end{array}$} & \multicolumn{4}{|c|}{ Maximum flood } \\
\hline & & & & Date & $\begin{array}{l}\text { Gage } \\
\text { height } \\
\text { (ft) }\end{array}$ & $\begin{array}{l}\text { Dis- } \\
\text { eharge } \\
\left(\mathrm{ft}^{3} / \mathrm{s}\right)\end{array}$ & $\begin{array}{l}\text { Recurence } \\
\text { Interval } \\
\text { (yrs) }\end{array}$ \\
\hline 05455140 & $\begin{array}{l}\text { North English R. } \\
\text { nr Montezuma }\end{array}$ & $1973-79$ & 31.0 & $7 / 20 / 78$ & 28.18 & 6,800 & 70 \\
\hline 05455150 & $\begin{array}{l}\text { North English R. } \\
\text { nr Montezuma }\end{array}$ & $1953-73$ & 34.0 & $5 / 24 / 53$ & 13.25 & 4,240 & 15 \\
\hline 05455200 & $\begin{array}{l}\text { North English R. } \\
\text { nr Guernsey }\end{array}$ & $1953-79$ & 68.7 & $5 / 24 / 53$ & 11.70 & $7,0.00$ & 25 \\
\hline 05455210 & $\begin{array}{l}\text { North English R. } \\
\text { at Guernsey }\end{array}$ & $\begin{array}{l}1960 \\
1966-79\end{array}$ & 81.5 & $9 / 18 / 77$ & 87.36 & 7,000 & 12 \\
\hline 05455230 & $\begin{array}{l}\text { Deep R. } \\
\text { at Deep River }\end{array}$ & $\begin{array}{l}1960 \\
1966-79\end{array}$ & 30.5 & $5 / 20 / 70$ & 83.85 & 6,200 & 50 \\
\hline 05455280 & $\begin{array}{l}\text { South English R. } \\
\text { trib. - Barnes City }\end{array}$ & $1953-76$ & 2.41 & $3 / 2 / 70$ & 9.04 & 900 & 8 \\
\hline 05455300 & $\begin{array}{l}\text { South English R. } \\
\text { nr Barnes City }\end{array}$ & $1953-79$ & 11.5 & $8 / 5 / 70$ & 13.16 & 1,850 & 7 \\
\hline 05455350 & $\begin{array}{l}\text { South English R. } \\
\text { trib. no. } 2 \\
\text { nr Montezuma }\end{array}$ & $1953-79$ & 0.62 & $7 / 27 / 61$ & 13.65 & 344 & 5 \\
\hline 05455500 & $\begin{array}{l}\text { English R. } \\
\text { at Kalona }\end{array}$ & $\begin{array}{l}1930 \\
1940-79\end{array}$ & 573 & $9 / 21 / 65$ & 21.45 & 20,000 & 35 \\
\hline 05455550 & $\begin{array}{l}\text { Bulgers Run } \\
\text { nr Riverside }\end{array}$ & $1965-79$ & 6.31 & $9 / 21 / 65$ & 89.04 & 3,080 & 45 \\
\hline
\end{tabular}


unobstructed. Stream-flow records at gaging stations are important control points in the definition of the flood profiles presented in this report.

In order to reference all the points along the profiles to a common datum, extensive leveling work was performed during wich at least one bench mark and a reference point were established at each bridge in the profiled reaches. Bench wark and reference point descriptions and elevations are listed in the section on reaporary Bench Harks.

\section{FLOOD FREQUEHCIES}

The discharge and frequency of lood flows listed in table 2 for the English River gaging station at Ralona vere conputed using methods outlined in O.S. Water Resources Council Bulletin 17a (1977).

Figure 3 shows the regionalized 100-year flood as defined by Lara (1973). This relationship of the 100-year flood to the drainage area can be used to estimate preliminary 100-year flood discharges at ungaged sites. The 100-year flood for the English River at Kalona agrees closely with the regionalized flood discharge. The annual flood peak discharges for each crest-stage gage can be evaluated for more specific Elood-frequency discharges at the site of the gage. 
Table 2.--Discharge and frequency of flood flows for continuousrecord gaging station in the English River basin

\begin{tabular}{|c|c|c|c|c|c|c|c|}
\hline \multirow{2}{*}{$\begin{array}{l}\text { Station } \\
\text { number }\end{array}$} & \multirow[t]{2}{*}{ Station name } & \multicolumn{6}{|c|}{$\begin{array}{l}\text { Discharge, in cubic feet per second, for indicated } \\
\text { recurrence interval, in years }\end{array}$} \\
\hline & & 2 & 5 & 10 & 25 & 50 & 100 \\
\hline
\end{tabular}

Note: Discharges computed by methods given in Bulletin 17A (U.S. Water Resources Council, 1977)

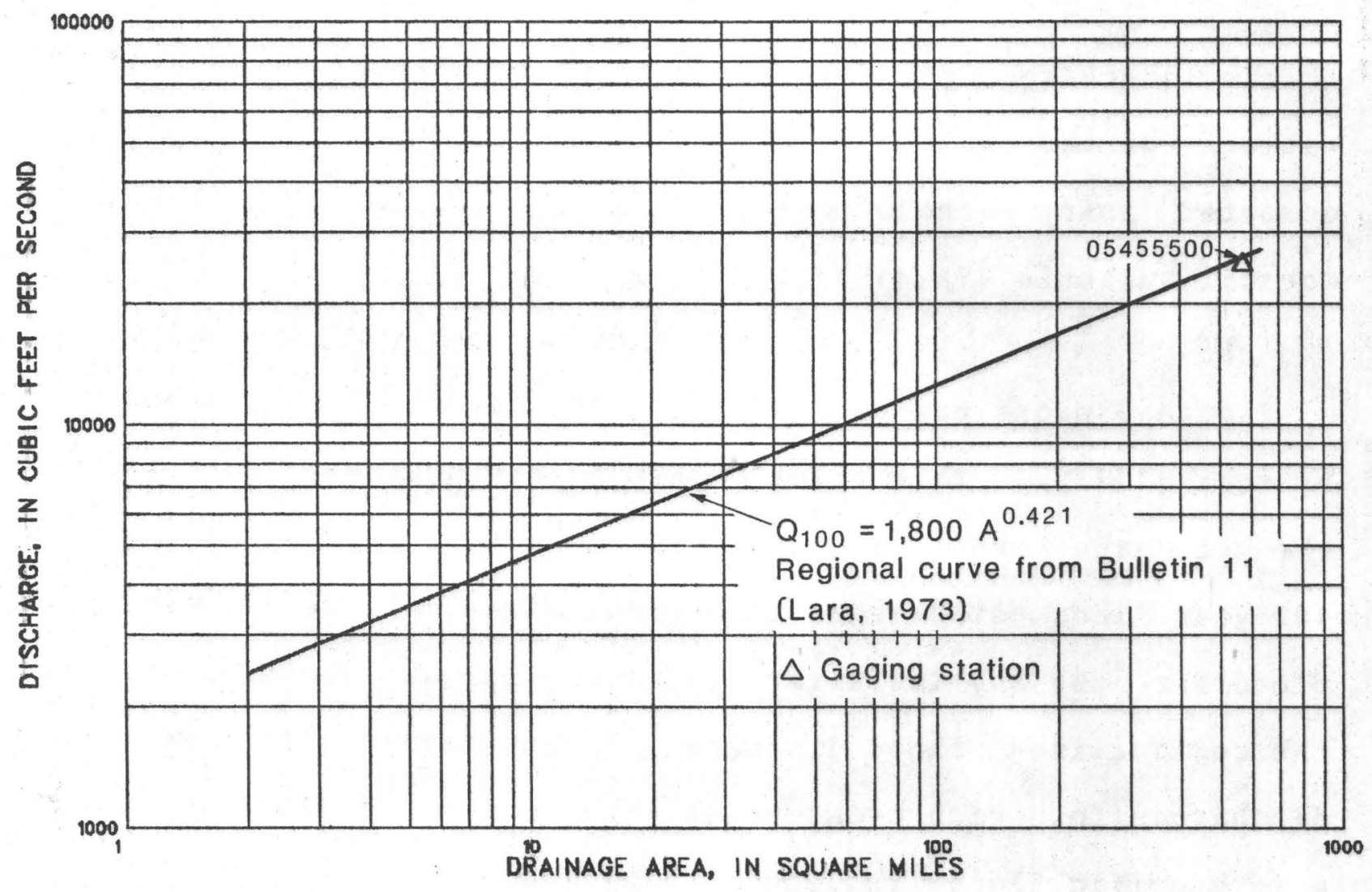

Figure 3. Relationship of regional 100-year flood discharge with drainage area for streams in English River basin. 
Figures 4-14 show profiles of the lay 1974 flood on the English River and some of its principal tributaries. The profiles were defined by field data obtained by the 0.5 . Geological survey. To define these profiles, high-water marks located both upstream and dounstrea frow bridges were identified and marked within a few days of passage of the flood peaks. The arks vere referenced to a comon datur by leveling. Low-water profiles are also shown on the figures to indicate the approximate range of stage that applies along the profiled reaches. Also shown on the figures are segwents of the 1965 and 1966 floods. Discharges at gaging stations for the profiles are noted on the appropriate illustrations.

River ileages, deterained from the best available maps. are referenced to the mouth of the Bnglish Biver. Bridges and a few other points are designated by an index nuber that helps to identify their location. For example. 7707-18 su refers to a location in township 77 north, range 07 west. and the southwest quarter of section 18 . 
Flood agnitude-frequency relationships in this basin are not wall defined except for the ain ste of the Bnglish River. More flood peak data sites and longer periods of streamflow record will further improve the reliability of the nagnitude-frequency relationships for streass in the basin. Farthernore, these relationships are subject to continuing odification by factors such as changing weteorologic and climatic trends, and physical changes in the basin such as urbanization, installation of drainage systems, reservoir development, and shifting land use.

The hydraulics of the English River systen are also not vell defined. Mide, flat flood plains are typical of a part of the basin. stage-discharge relationships for these areas are subject to seasonal changes because of the varying vegetative cover on the flood plain throughout the year.

Debris and ice jams, both nearly impossible to predict, can cause dranatic temporary changes in stage-discharge re1ationships. Natural scour and fill, channel straightening and construction of bridges and levees can cause more lasting changes. 
Thus, a river basin and its channel system are dynaic entities undergoing continual change. The relationships presented in this report represent the conditions existing at the time the field data were obtained.

\author{
REFERENCES
}

Lara, O.G.. 1973, Floods in Iowa: Technical manual for estimating their magnitude and frequency: Iowa Matural Resources Council Bulletin no. $11,40 \mathrm{p}$.

U.S. Geological Survey, issued annually to 1960, Surfacewater supply of the United States, part 5, Hudson Bay and Upper Mississippi River basins, 0.S. Geological Survey Water-supply Papers.

- issued annually since 1961, Nater resources data for Iowa, 0.S. Geological Survey Open-file Reports, Iowa City. Iowa, U.S. Geological survey.

U.S. Water Resources Council, 1977, Guidelines for determining flood flow frequency. Hydrology comittee Bulletin No. 17A. 


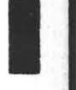

1

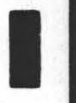

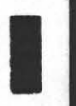

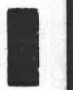

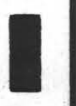

I

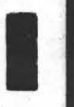

I

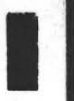

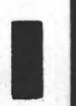

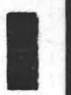

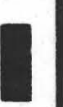

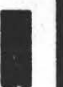

I

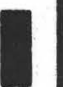

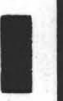

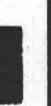

] 
Figure 4, page 13

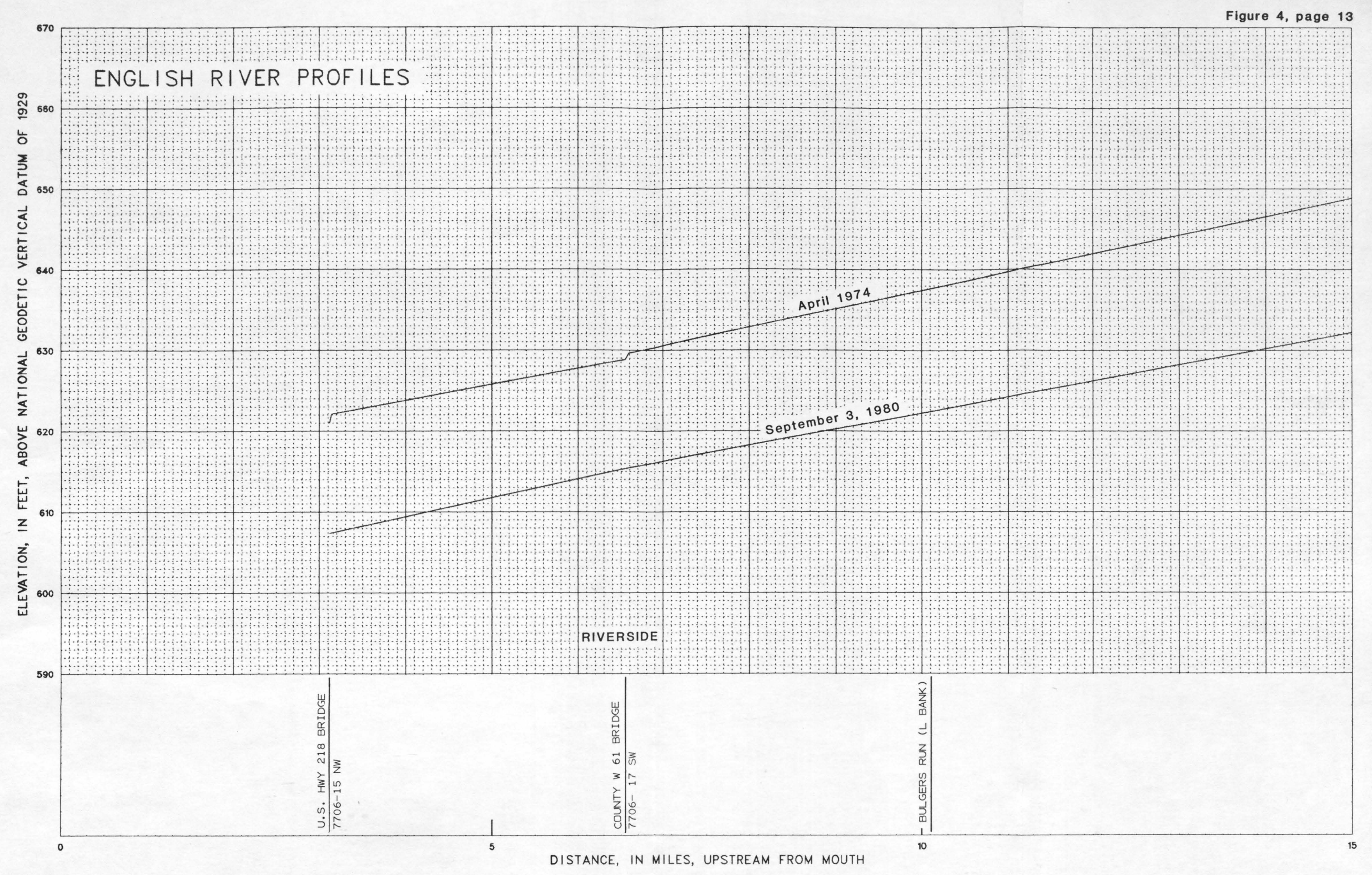




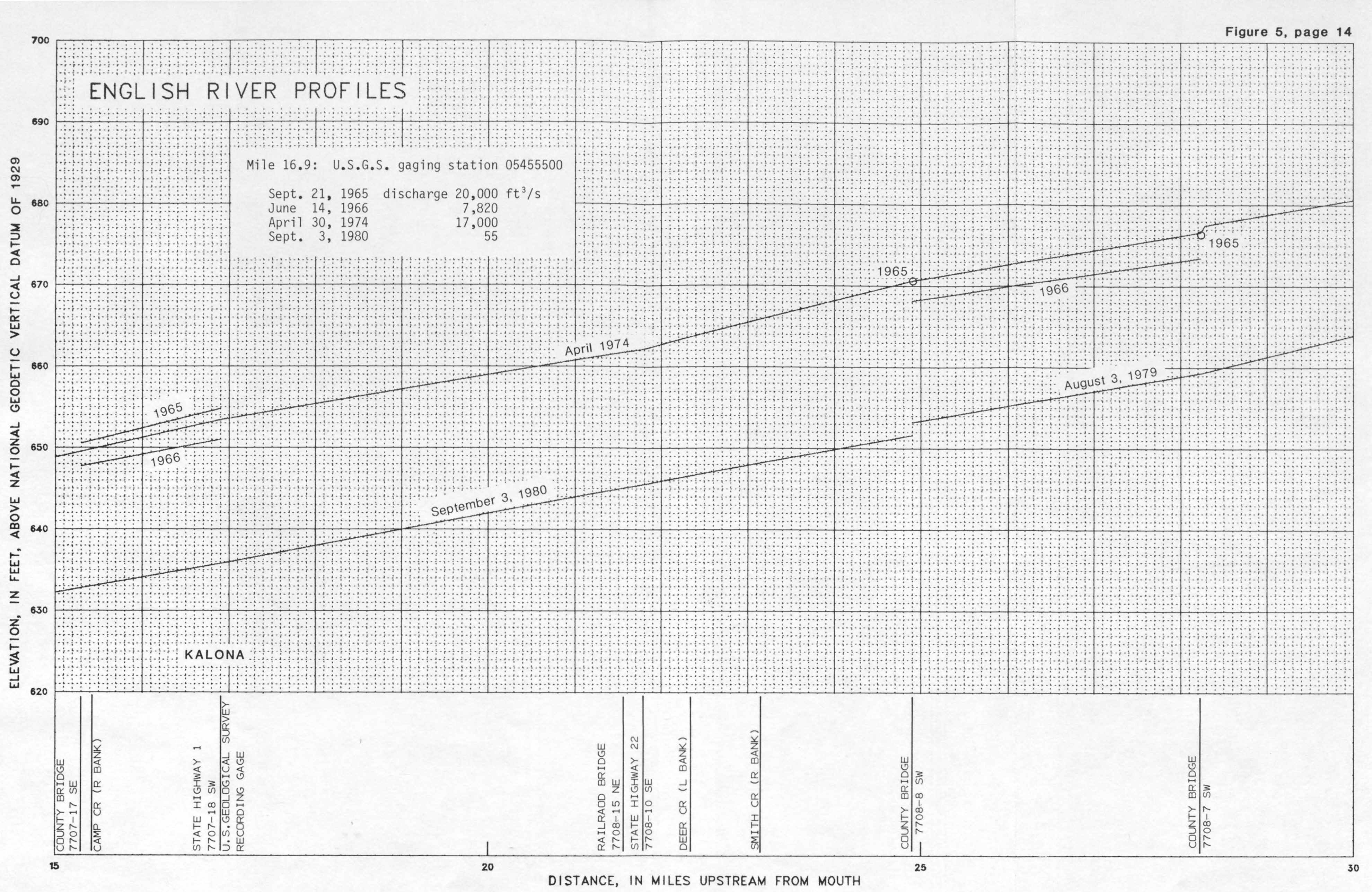




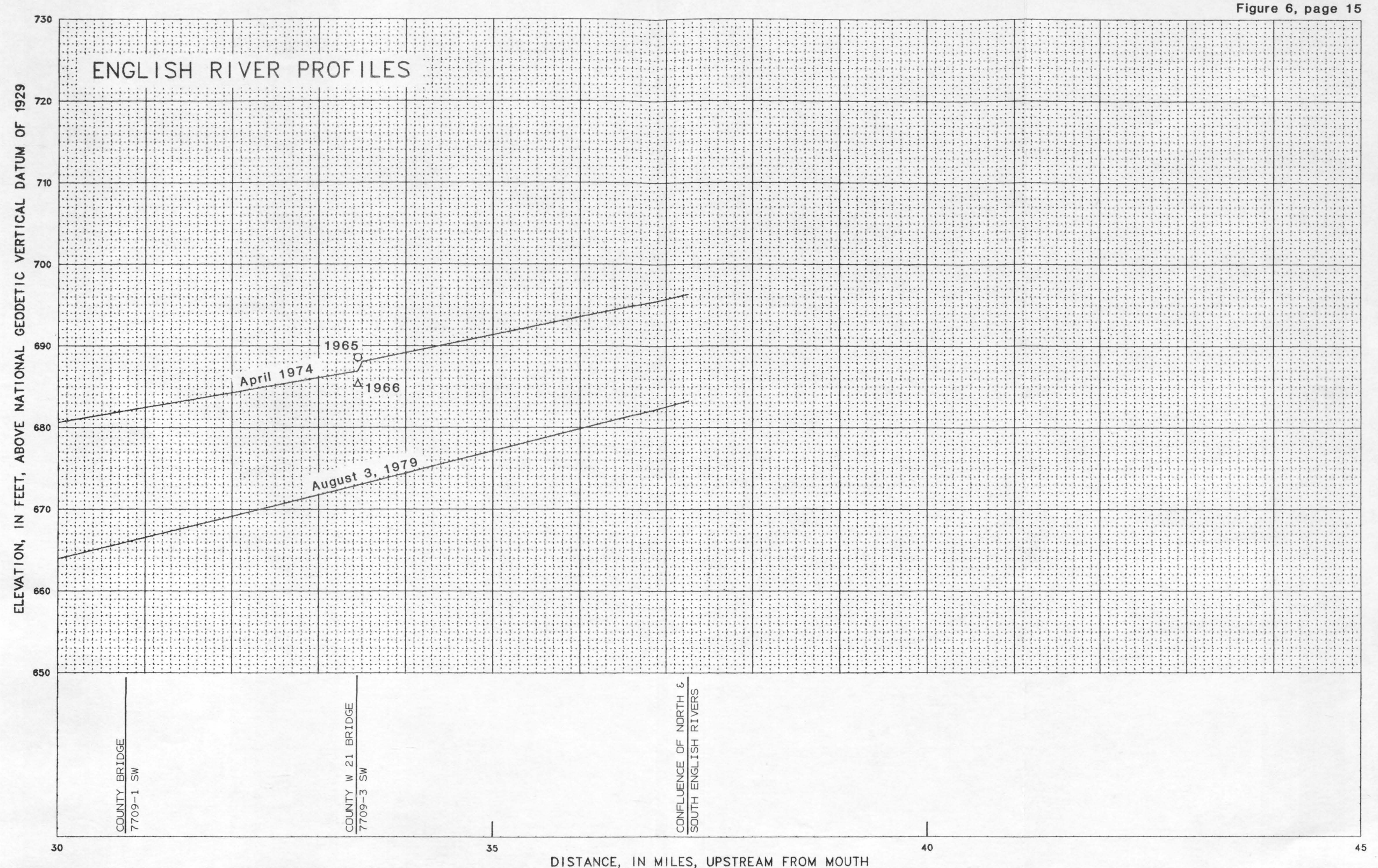









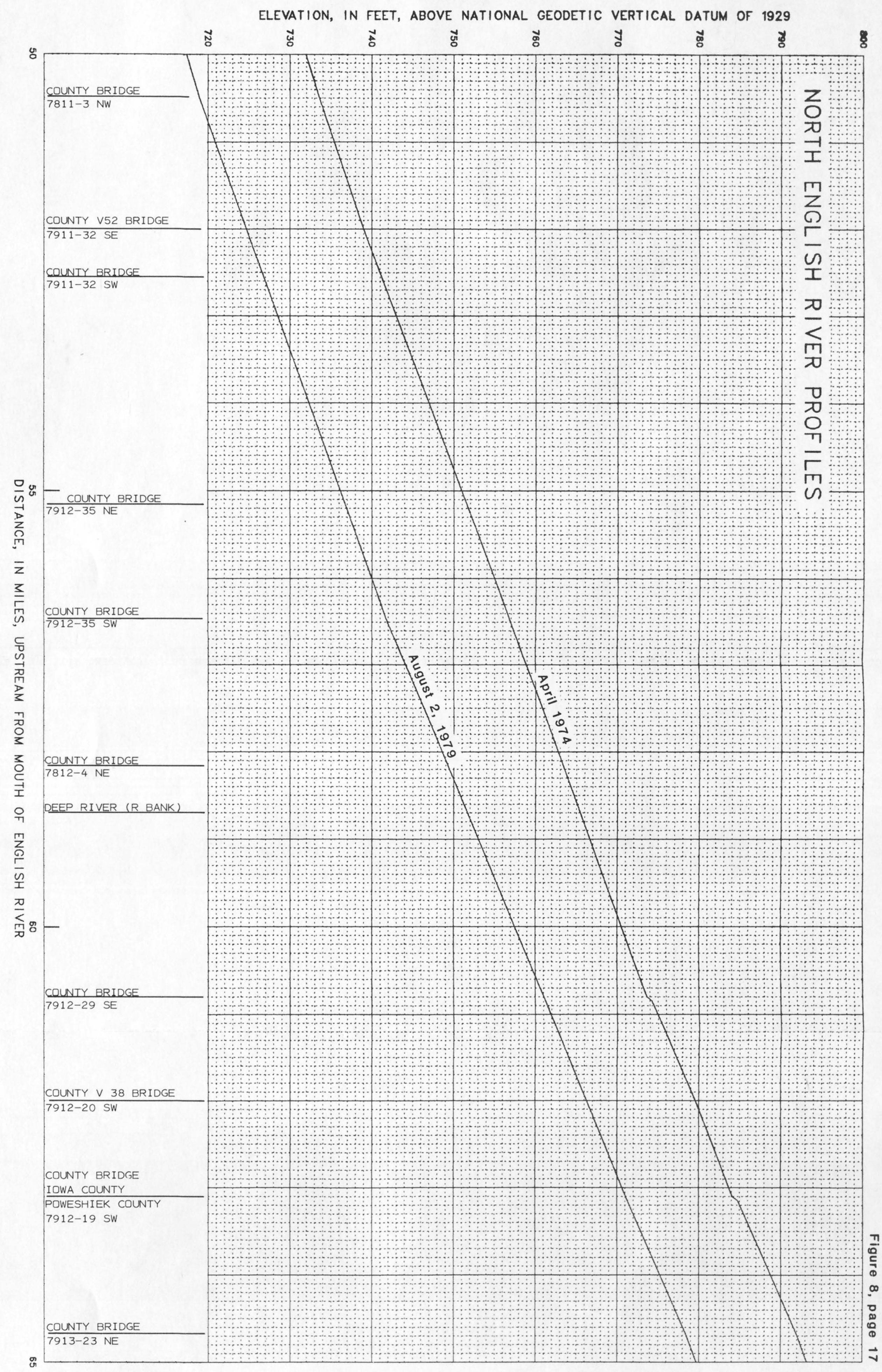




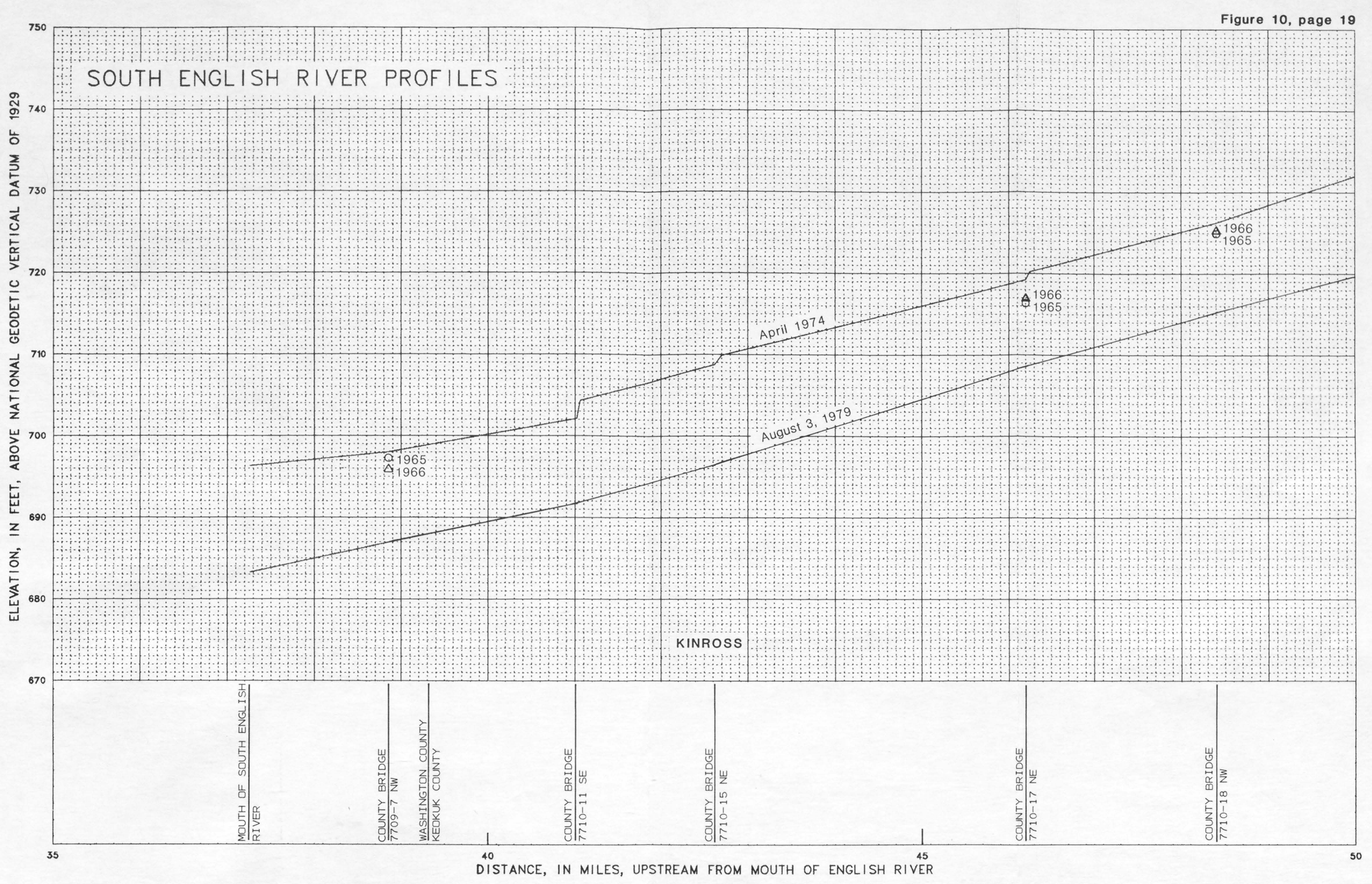


ELEVATION, IN FEET, ABOVE NATIONAL GEODETIC VERTICAL DATUM OF 1929

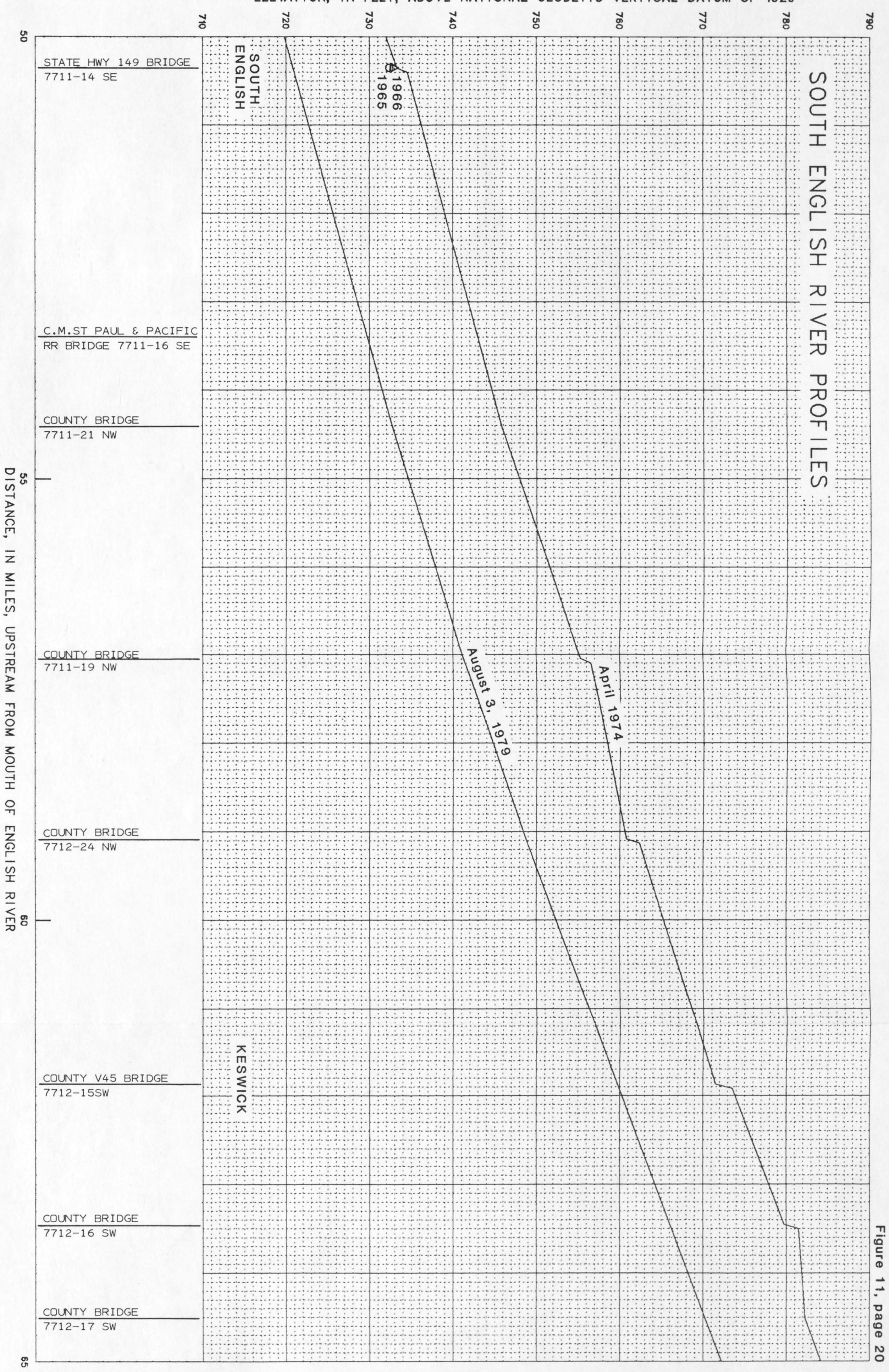




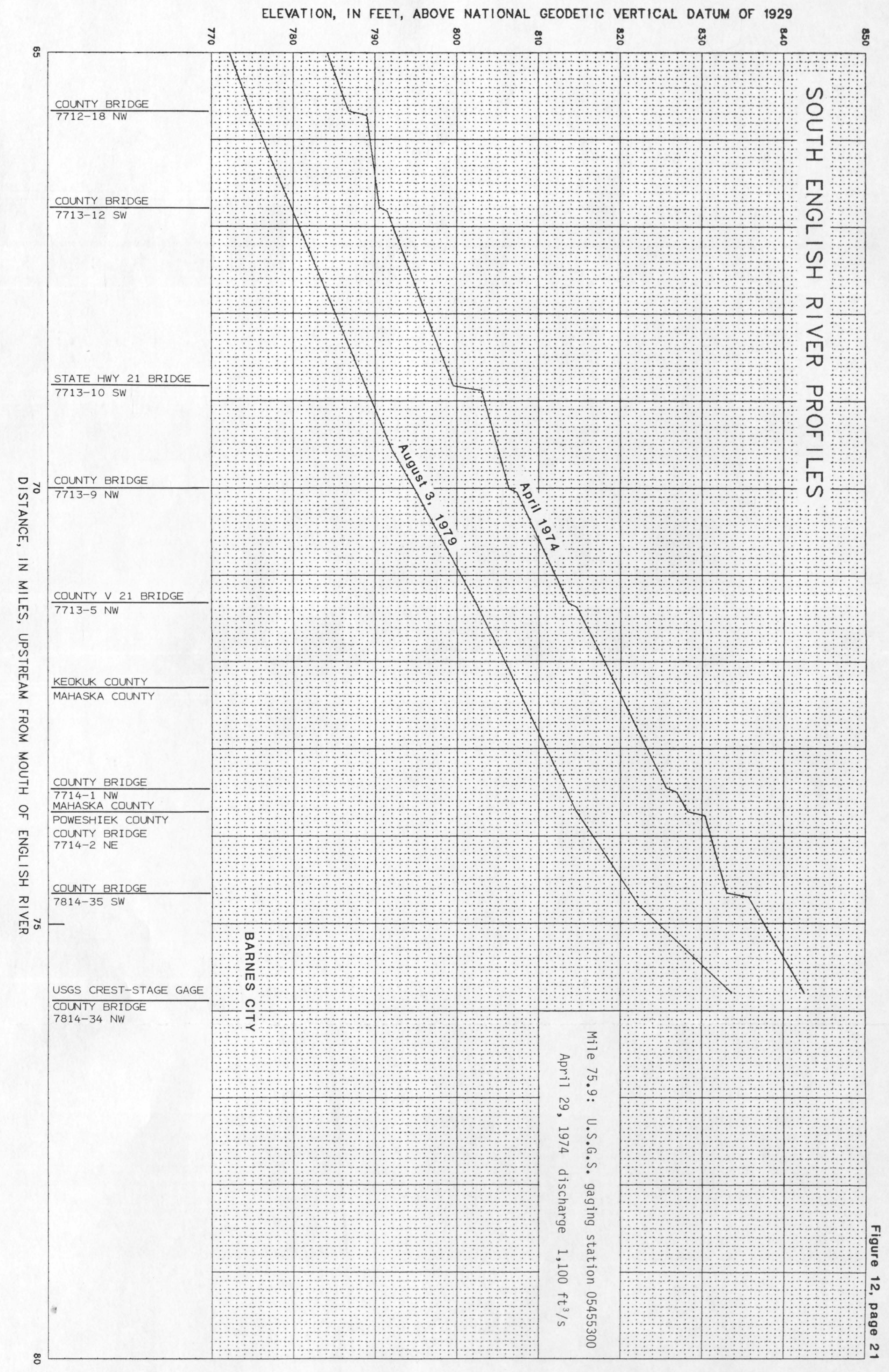









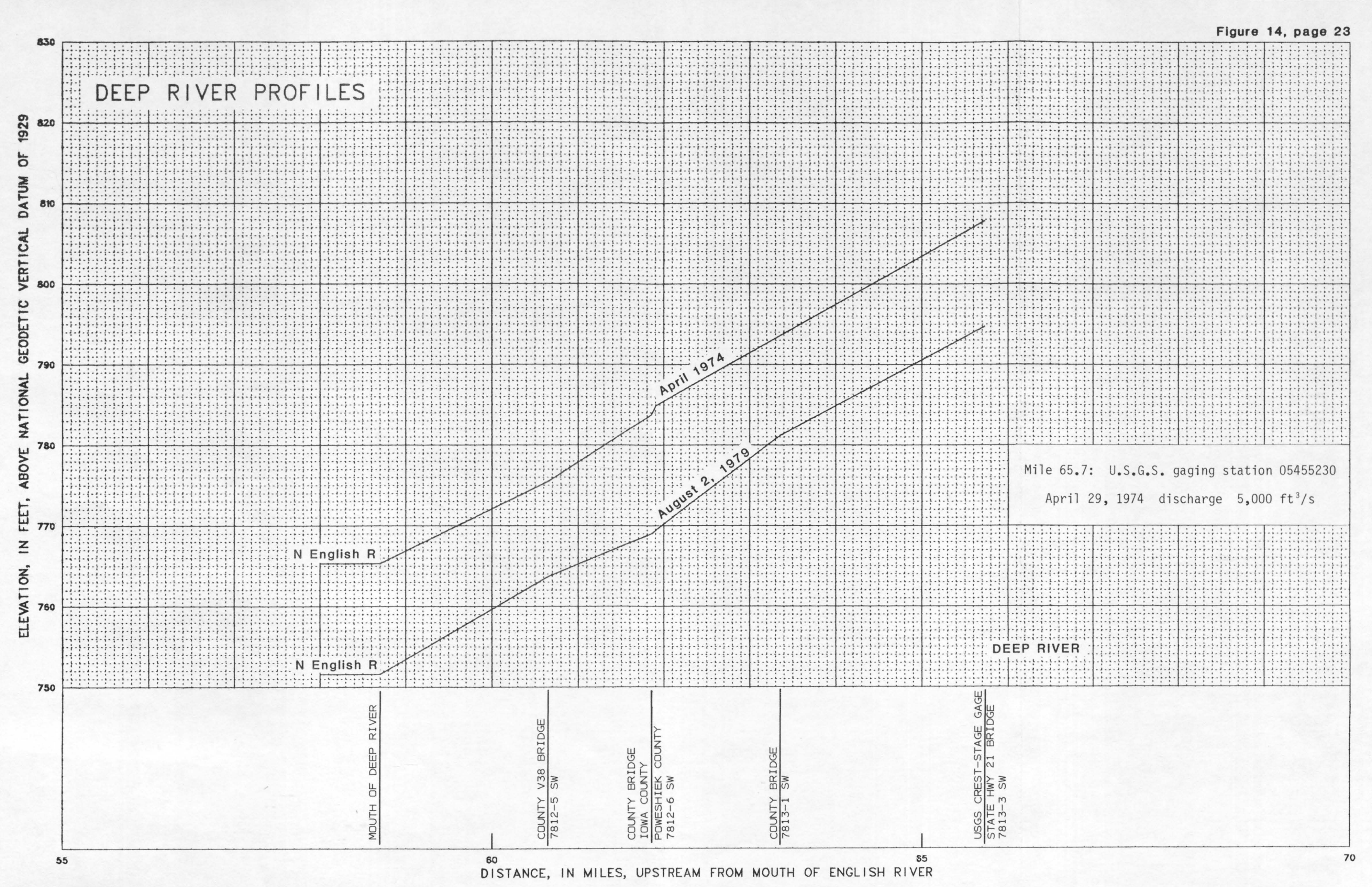


The following data on peak stages and discharges vere conpiled through Sept. 30, 1975, by Lara (1976), and were updated through sept. 30. 1979. for this report. The flood events are designated by calendar date and grouped by water year (year ending september 30). Por the partial-record stations, those equipped with crest-stage gages, only the annual flood peaks are listed. In general. for the continuous-record stations, independent flood peaks above a pre-selected base are listed (partial-duration series). This base discharge, given in the "Revarks" paragraph, was determined so that it would be equaled or exceeded on an average of about three times per year. Two flood peaks are considered independent if the discharge of the trough between then is 25 percent or nore below that of the lover peak.

The gaging-station records are arranged in the downstrean order explained in the annual water resources data reports of the 0.S. Geological Survey (See References). Each gaging station is identified by a permanent number that is also used in figures 1 and 3 and in tables 1 and 2. The datur of the gage, when given, is in feet above Mational Geodetic Vertical Datun of 1929 (previously called "mean sea level, 1929"). Bankfull and flood stages are given for some of the stations. Bankfull stage. as determined by the U.S. Geological survey, is the stage at which a strea first overflows its banks. Plood stage, howerer. as determined by the National Meather Service, is the stage at which overflow of the natural banks of the stream begins to cause danage in the reach in which the stage is measured. 
